OPEN ACCESS

Edited by:

Christos Dimitrios Arvanitidis, Hellenic Centre for Marine Research (HCMR), Greece

Reviewed by:

Tereza Manousaki,

Hellenic Centre for Marine Research (HCMR), Greece

Maria Cristina Gambi,

Stazione Zoologica Anton Dohrn, Italy

${ }^{*}$ Correspondence:

Gidon Winters

wintersg@adssc.org

†'Present address:

Hung Manh Nguyen,

Integrative Marine Ecology, Stazione

Zoologica Anton Dohrn, Naples, Italy

Narendra Singh Yadav,

University of Lethbridge, Lethbridge,

$A B$, Canada

Specialty section:

This article was submitted to

Marine Ecosystem Ecology,

a section of the journal

Frontiers in Marine Science

Received: 28 September 2019

Accepted: 16 December 2019

Published: 10 January 2020

Citation:

Nguyen HM, Yadav NS, Barak S, Lima FP, Sapir Y and Winters G (2020)

Responses of Invasive and Native Populations of the Seagrass Halophila

stipulacea to Simulated Climate Change. Front. Mar. Sci. 6:812. doi: 10.3389/fmars.2019.00812

\section{Responses of Invasive and Native Populations of the Seagrass Halophila stipulacea to Simulated
Climate Change}

\author{
Hung Manh Nguyen ${ }^{1,2+}$, Narendra Singh Yadav ${ }^{3 t}$, Simon Barak ${ }^{3}$, Fernando P. Lima ${ }^{4}$, \\ Yuval Sapir ${ }^{2}$ and Gidon Winters ${ }^{1 *}$
}

\begin{abstract}
1 The Dead Sea Arava Science Center, Jerusalem, Israel, ${ }^{2}$ Yehuda Naftali Botanic Garden, School of Plant Sciences and Food Security, Tel-Aviv University, Tel Aviv, Israel, ${ }^{3}$ French Associates Institute for Agriculture and Biotechnology of Drylands, Jacob Blaustein Institutes for Desert Research, Ben-Gurion University of the Negev, Beersheba, Israel, ${ }^{4}$ Research Center in Biodiversity and Genetic Resources, University of Porto, Porto, Portugal
\end{abstract}

Climate change fuels invasions of plant species and displacement of local plants. Little is known about the ecophysiological adaptation of the invasive species, and their ability to cope with the changing conditions in their new habitat. Halophila stipulacea, a tropical seagrass native to the Gulf of Aqaba (GoA; northern Red Sea), became a Lessepsian migrant spreading within the eastern Mediterranean where it could potentially outcompete local species. We analyzed temperature records in the last 35 years and show that water temperature has increased faster in the eastern Mediterranean Sea compared to GoA, suggesting that $H$. stipulacea's invasive success is associated with adaptation to thermal warming. Furthermore, we compared the responses of native (Eilat, Israel) and invasive (Limassol, Cyprus) $H$. stipulacea plants to current $\left(26^{\circ} \mathrm{C}\right)$ and predicted thermal maxima $\left(29\right.$ and $\left.32^{\circ} \mathrm{C}\right)$ in a controlled experimental microcosm. Morphological and photo-physiological results showed negative effects of heat stress on the native plants while un-affected/or even enhanced performance in their invasive counterparts. Gene expression, studied for the $1^{\text {st }}$ time in $\mathrm{H}$. stipulacea, pointed to differences in the molecular responses of two populations to thermal stress. Results predict that sea warming will cause vast reductions in $\mathrm{H}$. stipulacea meadows growing in the GoA while it will facilitate H. stipulacea's spread within the Mediterranean Sea.

Keywords: thermal stress, global warming, Halophila stipulacea, invasive species, Lessepsian migrant, tropical seagrass

\section{INTRODUCTION}

Seagrass meadows thrive worldwide in shallow sedimentary shorelines, where they fulfill important ecological services (including high primary productivity, production, and burial of organic carbon, nutrient cycling, and sediment stabilization) estimated at US\$2.8 $\times 10^{6} \mathrm{~km}^{-2} \mathrm{yr}^{-1}$ (Costanza et al., 2014). Yet, seagrass ecosystems are facing a global crisis due to both direct (reduced water quality, coastal development, and poor land use) and indirect (climate change) anthropogenic perturbations (Orth et al., 2006; Waycott et al., 2009; Short et al., 2011). Loss of seagrass ecosystems 
entails devastation of the associated biodiversity and primary productivity, reduction of local fishing grounds, enhancement of coastal erosion, and loss of major carbon sinks culminating in ecological and socio-economic dislocations (Wyllie-Echeverria and Cox, 1999; Orth et al., 2006; Fourqurean et al., 2012; Costanza et al., 2014; Arias-Ortiz et al., 2018). Increasing seawater temperatures associated with global warming directly affect seagrasses in several ways, including changes in growth rates, physiological functions, patterns of sexual reproduction, phenology, and seed germination (Marbà et al., 1996; Orth et al., 2006; Marbà and Duarte, 2010; Jordà et al., 2012). In addition, ocean warming and the associated increase in the frequency, duration and severity of heat waves (Easterling et al., 2000; Schär et al., 2004; Oliver et al., 2018) act indirectly by facilitating the establishment and spreading of invasive species (Stachowicz et al., 2002; Bradley et al., 2010) alongside reducing the biotic resistance of native communities to invader establishment (Diez et al., 2012).

The seagrass Halophila stipulacea (Forsskål) Ascherson (order Alismatales, family Hydrocharitaceae) is a dioecious, small tropical species native to the Red Sea, Persian Gulf, and Indian Ocean (den Hartog, 1970; Green and Short, 2003). Within the northern Gulf of Aqaba (GoA), one of the focal regions of this study, $H$. stipulacea is the most dominant, and sometimes only seagrass species (El Shaffai, 2011; Mejia et al., 2016), forming extensive mono-specific meadows found in both shallow and deep environments (1-50 m depth; Sharon et al., 2011; Winters et al., 2017), in soft sediments ranging from fine sand to gravel (Mejia et al., 2016; Rotini et al., 2017).

Following the opening of the Suez Canal in 1869, H. stipulacea soon became a Lessepsian migrant (den Hartog, 1972; Lipkin, 1975a) and has since become established in many parts of the eastern Mediterranean Sea (Lipkin, 1975a,b; van der Velde and den Hartog, 1992; Gambi et al., 2009; Katsanevakis and Tsiamis, 2009; Sghaier et al., 2011). Surprisingly, in 2002 H. stipulacea was also reported from the Caribbean Sea (Hector and David, 2004), and merely a decade later it was found in most Eastern Caribbean island nations as well as along the coast of the continental South American (Willette and Ambrose, 2009, 2012; Maréchal et al., 2013; Vera et al., 2014; Willette et al., 2014; Steiner and Willette, 2015; van Tussenbroek et al., 2016; Scheibling et al., 2018). In the Caribbean, $H$. stipulacea has been shown to displace native Caribbean seagrass species (e.g., Syringodium filiforme, Halodule wrightii, and Halophila decipiens) by physically displacing local Caribbean seagrass species by monopolizing their spaces (Willette and Ambrose, 2012), leading to a major change in the Caribbean's seagrass landscape (Steiner and Willette, 2015).

Although $H$. stipulacea was included in the "100 Worst Invasive Alien Species in the Mediterranean" (Streftaris and Zenetos, 2006), in this basin, evidence for its "invasive" characteristics are scarce. Observations point toward a relatively limited "invasion success" in this region, as can also be inferred from the limited number of studies reporting competitive displacement of native Mediterranean seagrasses by the invasive H. stipulacea (Georgiou et al., 2016). However, some evidence of the potential competitive displacement by the invasive or "alien" H. stipulacea does exist. Sghaier et al. (2014) showed that a small patch (0.2 ha) of H. stipulacea in Cap Monastir Marina (eastern Tunisian coast), grew to cover more than 2.2 ha in only 4 years, and, in the process, displaced $50 \%$ of the native Cymodocea nodosa. More evidence of the future potential of H. stipulacea in the Mediterranean, comes from its slow (12 km $\mathrm{yr}^{-1}$; Chiquillo et al., 2018) but continuous spread and expansion in this basin, moving westwards and northwards (Lipkin, 1975a; Gambi et al., 2009, 2018; Sghaier et al., 2011).

As $H$. stipulacea seems to be highly adapted to a wide range of environmental conditions (Gambi et al., 2009; Sharon et al., 2011) it has been predicted that the ongoing tropicalization of the Mediterranean Sea (i.e., becoming warmer and saltier; Bianchi and Morri, 2003; Borghini et al., 2014; Ozer et al., 2017) accompanied by the recent doubling of the Suez Canal (Galil et al., 2015) can facilitate $H$. stipulacea to outcompete local seagrass species (Sghaier et al., 2014) or to occupy newly available habitat following extirpation of local Mediterranean temperate seagrass species (Marbà and Duarte, 2010; Jordà et al., 2012; Chefaoui et al., 2018; Marín-Guirao et al., 2018; Savva et al., 2018).

In addition to the changing Mediterranean, $H$. stipulacea is also facing climate change within its native range, e.g., the northern GoA (Fine et al., 2013). Surrounded by deserts, the GoA receives very little rain and practically no runoffs from neighboring arid lands, creating an oligotrophic and warm tropical sea (Winters et al., 2006; Reiss and Hottinger, 2012). While studies have highlighted the potential effects of ocean warming on local coral reefs (Fine et al., 2013), little is known about the thermal tolerance of local $H$. stipulacea. In the GoA, where the tropical H. stipulacea is often found in meadows neighboring coral reefs (Mejia et al., 2016; Winters et al., 2017), loss of $H$. stipulacea could lead to increased sediment re-suspension, nutrient, and particulate loading into the water column (Orth et al., 2006) with adverse consequences to neighboring coral reefs due to algal overgrowth (Genin et al., 1995). Since tropical seagrass meadows also modify seawater carbonate chemistry by taking up $\mathrm{CO}_{2}$, potentially mediating the effects of ocean acidification (Unsworth et al., 2012), loss of $H$. stipulacea meadows in the GoA would also enhance the decalcification process of neighboring corals (Hoegh-Guldberg et al., 2007). The fact that many reef fish species tend to hide in the structurally complex coral reefs to avoid predators, but forage in nearby structurally simple tropical seagrass meadows (Beck et al., 2006), entails that loss of seagrass meadows in the GoA will have cascading effects on local biodiversity.

Increased seawater temperatures can alter growth rates and other physiological and biochemical functions of seagrass (Short and Neckles, 1999; Beca-Carretero et al., 2018). With photosynthesis being among the first processes to be affected by elevated temperatures (Sharkey, 2005), several studies on the effects of thermal stress on seagrasses have focused on changes in photophysiological parameters (Ralph, 1998; Campbell et al., 2006; Winters et al., 2011). While studying gene expression is emerging as an important tool in seagrass thermal stress studies (Procaccini et al., 2012; Davey et al., 2016), so far, this was only applied in temperate seagrass species (Bergmann et al., 2010; Winters et al., 2011; Davey et al., 2016; 
Marín-Guirao et al., 2016), with no molecular studies ever performed in tropical seagrass species.

In both the eastern Mediterranean and the northern GoA, understanding the thermal tolerance of local $\mathrm{H}$. stipulacea populations is crucial for seagrass conservation and management. The objective of the present study was to test whether $H$. stipulacea plants from native and invasive populations differ in performance and ecophysiology under thermal conditions that simulate current and future climate changes. We first analyzed temperature records and warming trends in the northern GoA (Eilat, Israel) and the eastern Mediterranean Sea (Limassol, Cyprus). We then collected plants from both native (GoA) and invasive (Limassol) H. stipulacea populations and compared their physiological, biochemical and molecular responses to current $\left(26^{\circ} \mathrm{C}\right)$ and predicted thermal maxima $\left(29\right.$ and $\left.32^{\circ} \mathrm{C}\right)$ in a microcosm setup. Results suggest a rapid adaptation of the invasive population to the ongoing warming of the Mediterranean Sea. We predict that sea warming will cause vast reductions in $H$. stipulacea meadows growing in the GoA while facilitating their spread within the Mediterranean Sea. These results have important implications for biodiversity management and conservation in both of these regions.

\section{MATERIALS AND METHODS}

\section{Plant Materials and Habitat Descriptions}

Halophila stipulacea plants (with shoots, attached roots, and rhizomes) were collected at $4 \mathrm{~m}$ depth from both an invasive (Limassol, eastern Mediterranean Sea, Cyprus; $34^{\circ} 42^{\prime} 20^{\prime \prime} \mathrm{N}$, $33^{\circ} 07^{\prime} 24^{\prime \prime}$ E; Figures 1A,B,D) and from a native population (Eilat, northern GoA, Israel; $29^{\circ} 32^{\prime} 47^{\prime \prime} \mathrm{N}, 34^{\circ} 57^{\prime} 51^{\prime \prime} \mathrm{E}$; Figures 1A,C,E) on September $29^{\text {th }} 2017$ and October $3^{\text {rd }}$, respectively ( $n=200$ plants collected at each site; Figure 1A). The population growing in Limassol ("dream café" site; Figures 1B,D), came from a shallow area $100 \mathrm{~m}$ from shore that was protected by detached breakwaters. In this area we found three seagrass species: Cymodocea nodosa, residual patches of Posidonia oceanica and the invasive of $H$. stipulacea mixed inbetween them (Figure 1D). Sediment at this site was sandy and the slope was very gentle. Similarly, the population growing in Eilat, came from a shallow meadow, $100 \mathrm{~m}$ from shore that is the northern-most tip of the GoA. In this area ("North Beach" site), H. stipulacea grows in extensive mono specific meadows that start at $2 \mathrm{~m}$ and extend to deeper waters (30 m, Winters et al., 2017). Sediment at this site was sandy and the slope was very gentle (Mejia et al., 2016). In both sites, the H. stipulacea plants that were collected, were at least $2 \mathrm{~m}$ away from each other in order to avoid collecting samples from the same clone. During collection, water temperatures at both sites were around $25-26^{\circ} \mathrm{C}$.

\section{Environmental Conditions at the Collection Sites}

While environmental conditions at the collection site in Eilat (e.g., seawater temperatures, salinity, sediment type, Kd and nutrient levels) have been described before (Mejia et al., 2016; Winters et al., 2017) and are well-monitored in nearby sites for nearly 20 years by the National Monitoring Program at the Gulf of Eilat (NMP-Israel ${ }^{1}$ ), no long-term dataset exists for anywhere near the Cyprus site. Thus, comparisons between the long-term conditions at the two sites were based on two data sets. To compare seawater salinities between the two sites, the Bio-ORACLE global dataset (Tyberghein et al., 2012; Assis et al., 2018) was used to compare minimum, maximum, and average values of water salinities over a relatively long-term data set (2000-2014, based on monthly averages; Supplementary materials S1). To compare environmental temperatures and rates of warming between study locations in Eilat and Limassol, we obtained daily sea surface temperatures (SSTs) for the period between 1982 and 2017 from the NOAA dOISST.v2 dataset at www.ngdc.noaa.gov (Smith, 2016). We used Advanced Very High-Resolution Radiometer (AVHRR) only data, due to its longer temporal span and because it has been shown to outperform other datasets in coastal areas (Lima and Wethey, 2012). For each of the two locations, daily climatology parameters were produced by averaging corresponding daily values over the entire time span. Average warming rates were computed as the slope of the linear regression of seasonally detrended SST versus time (Lima and Wethey, 2012). Seasonal variability was removed by subtracting from each day its corresponding climatology, i.e., the average temperature for that same day computed over the entire period under analysis (Chatfield, 2016). To compensate for temporal autocorrelation that could cause an underestimation of the standard errors of the warming rates, we followed Foster and Rahmstorf (2011) and reduced the data per effective degrees of freedom, using a conservative approach where autocorrelation structure was treated as an autoregressive moving average process by applying the ARMA $(1,1)$ model (Foster and Rahmstorf, 2011). Warming rates for February and August were computed based on averaged daily values for those months. All calculations were done in R Core Team (2018).

\section{Mesocosm Facility}

Collected plants were transferred to our seagrass dedicated microcosm facility in zip lock bags filled with seawater (Figure 2A; recently described in Oscar et al., 2018). Here plants were planted in 15 aquaria ( $40 \mathrm{~cm}$ width, $33 \mathrm{~cm}$ height, $45 \mathrm{~L}$ of seawater in each aquarium) layered with $20 \mathrm{~L}(\sim 7 \mathrm{~cm}$ high) of natural sediment (sediment collected from the shores of the GoA, Eilat; Figure 2A) and filled with artificial seawater (Red Sea Salt, Israel). Each aquarium contained 20 individuals (i.e., 10 invasive and 10 native plants) with invasive and native populations separated by plastic dividers (insert in Figure 2A). A total of 5 aquaria were assigned for each treatment and considered as experimental replicates ( $n=5$ in each treatment). Salinity was maintained at $40 \mathrm{PSU}$ (partial salinity units, equivalent to the average salinity of the GoA's seawater; The National Monitoring Program at the Gulf of Eilat, 2014 ${ }^{1}$ ) by adding purified water to compensate evaporation. In order to retain the quality of experimental seawater, $20 \%$ of the total volume of water in each aquarium was replaced by newly prepared seawater every week. This microcosm facility is fully controlled

${ }^{1}$ http://www.meteo-tech.co.il/EilatYam_data/ey_data.asp (accessed July 3, 2017) 


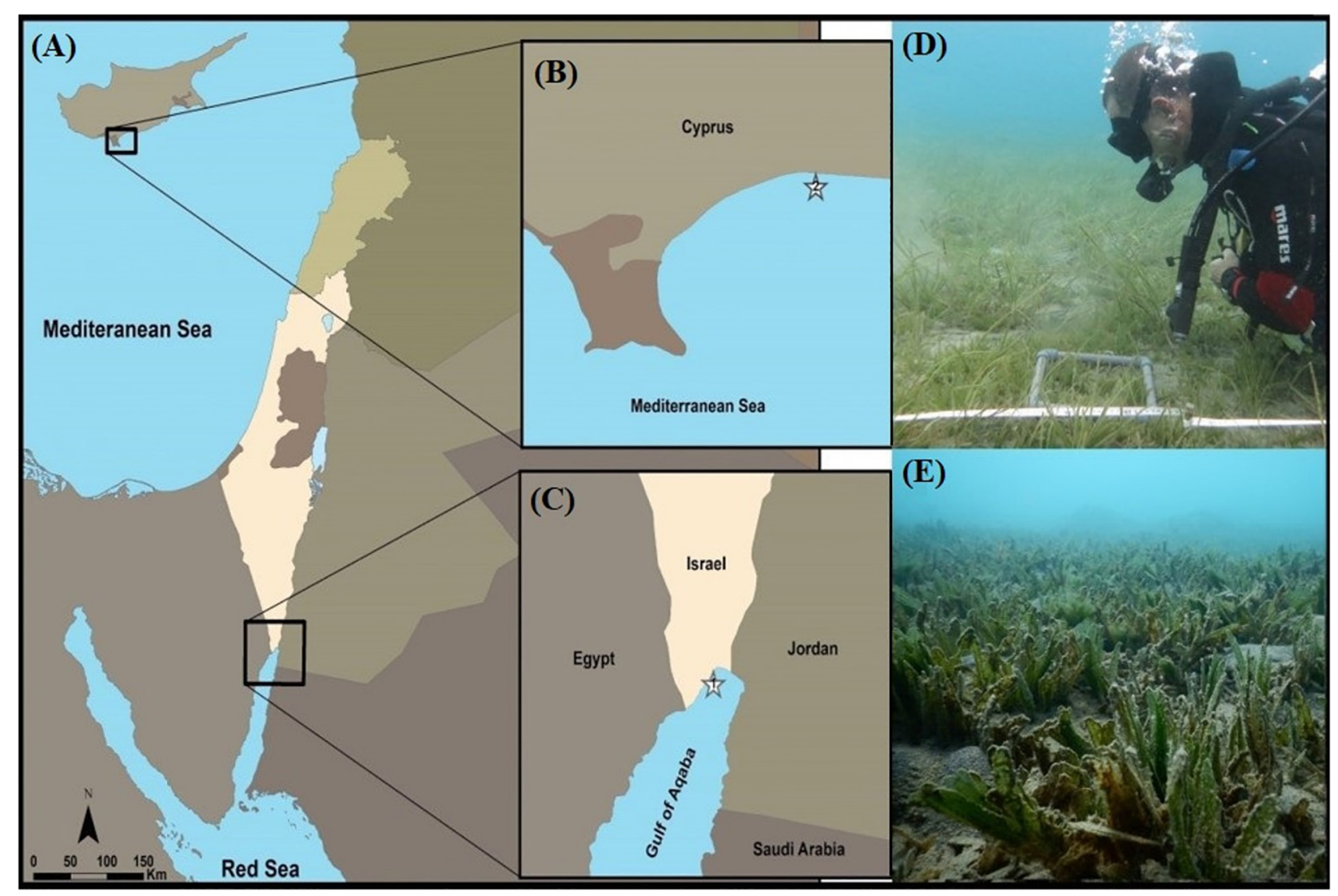

FIGURE 1 | Sampling sites of Halophila stipulacea (A-C): (1) The native population, North Beach site, Eilat, northern Gulf of Aqaba (GoA, northern Red Sea, Israel). (2) The invasive population, growing at the Dream Café site, Limassol (eastern Mediterranean Sea, Cyprus). (D) Invasive H. stipulacea plants growing intermixed with plants of the native Mediterranean seagrass Cymodocea nodosa at the Dream café site (Photo: Yuval Sapir). (E) H. stipulacea growing in its native habitat in the GoA (Photo: Hung Manh Nguyen). Depths of both plant collection sites 3-4 m.

for temperature and light (ProfiLux 3.1T eX Controller, GHL; GHL, Germany). Irradiance was provided by T5 fluorescent lamps (Osram Lumilux HO 865/54W cool daylight with the color temperature of 6500 degrees Kelvin) that were set to a 10:14 h light: dark cycle, with intensities of $120 \mu \mathrm{mol}$ photons s $\mathrm{s}^{-1} \mathrm{~m}^{-2}$ measured at the bottom of the aquaria.

Water temperatures were measured automatically every $1 \mathrm{~h}$ with PT1000 thermal sensors (GHL, Germany) connected to two ProfiLux 3.1T eX GHL controller systems (GHL, Germany). In each one of the three treatments (detailed below), water temperature was followed over time using two sensors, situated in two different aquaria belonging to the same treatment (Figure 2A). Salinity and temperature were also checked manually every day using the WTW Multi 340i Portable Meter (Xylem Analytics, Weilheim in Oberbayern, Germany). Each one of the 15 aquaria, was fit with a submersible pump to provide gentle water movement within the aquarium.

\section{Experimental Treatments}

Following 3 weeks of the acclimation period, heating treatments were applied. These included maintaining plants at $26^{\circ} \mathrm{C}$ (just under the current maximal summer water temperatures in Eilat;
Winters et al., 2006), and two predicted climate change scenarios, including 29 and $32^{\circ} \mathrm{C}$. The experiment was started by 1 week of gradual increases of the temperatures in the control tanks (from 25 to $26^{\circ} \mathrm{C}$ ) and in the two thermal stress treatments (from 25 to $29^{\circ} \mathrm{C}$, and from 25 to $32^{\circ} \mathrm{C}$, at heating rates of 1 and $0.5^{\circ} \mathrm{CC} \mathrm{day}{ }^{-1}$, respectively, Figure 2B). Plants were kept for 2 weeks at these high temperature treatments $\left(29\right.$ and $\left.32^{\circ} \mathrm{C}\right)$, after which, water temperatures were gradually ramped down (at cooling rates similar to those mentioned above) to $26^{\circ} \mathrm{C}$ at the end of the experiment, with measurements at T4 taken $24 \mathrm{~h}$ after reaching control temperatures (Figure 2B). Plants exposed to the control treatment were kept at $26^{\circ} \mathrm{C}$ throughout the entire experiment (Figure 2B).

\section{Plant Performance}

Plant performance was estimated by measuring a total number of shoots (shoots plant ${ }^{-1}$ ), horizontal growth rates $\left(\mathrm{mm} \mathrm{week}^{-1}\right.$ ), and leaf surface area $\left(\mathrm{cm}^{2}\right)$ before, during, and after the thermal stress treatment (Figure 2B). For this, three plants per population in each aquarium were randomly selected for measuring the total number of shoots every week, which were averaged into a single biological replicate (i.e., within each treatment, each 

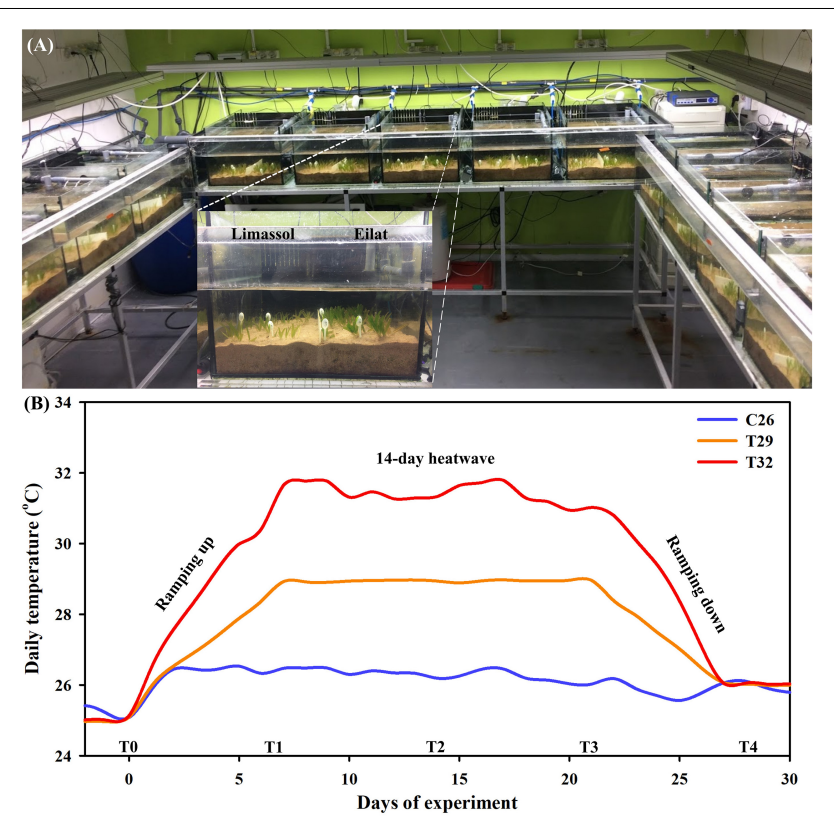

FIGURE 2 | The seagrass dedicated mesocosm facility, containing 15 aquaria fully controlled for water temperature, light, and salinity (A). Aquaria were layered with natural sediment and filled with artificial seawater. Each aquarium contained 10 invasive and 10 native $H$. stipulacea plants, separated by plastic dividers (A, inset). Average water temperature profiles $(n=2$ sensors in two tanks from each treatment) during the microcosm experiment (day 0-28) (B). Shown are the three thermal treatments $\left(26^{\circ} \mathrm{C}\right.$ [control], $29^{\circ} \mathrm{C}$ and $\left.32^{\circ} \mathrm{C}\right)$, the time points (TO-T4) on which measurements and samples were taken, and the different stages of the experiment - 6-days of ramping up the temperature, the 14-day heat wave, followed by 6-days of ramping temperatures down again to control levels $\left(26^{\circ} \mathrm{C}\right)$.

aquarium $=$ one biological replication). In addition, three plants were randomly selected per aquarium and used to assess horizontal growth rates once per week. For this, the distance from the basal leaf sheath to the tip of the three youngest leaves was measured and these three measurements were averaged into a single biological replicate. Finally, mature intact leaves (i.e., fully grown, often the third youngest shoot with leaf tip; broken leaf tips were not used) were detached from one plant per population in each aquarium once a week, scanned on a digital scanner (CanoScan LiDE 120, Canon U.S.A., Inc.) and leaf surface area was estimated by using ImageJ (Abràmoff et al., 2004).

\section{Biochemical Measurements}

Scanned leaves that were used for leaf surface area measurements (mentioned above) were subsequently used for measuring changes in chlorophyll $a$ and $b$ contents. Chlorophylls were extracted in 100\% methanol according to Wellburn (1994) and adapted to a 96 well microplate reader (Epoch 2 Microplate Spectrophotometer, Biotek) as described in Warren (2008). After scanning, leaves were immediately weighed and $50 \mathrm{mg}$ (fresh weight) of tissue was homogenized into small pieces before transferring into $1.5 \mathrm{~mL}$ tubes. $1 \mathrm{~mL}$ of $100 \%$ methanol was added into the tube, covered with aluminum foil, and kept at $4^{\circ} \mathrm{C}$ overnight. $200 \mu \mathrm{L}$ of chlorophyll extract was then transferred into a 96-well plate (CELLSTAR ${ }^{\circledR}$, Greiner Bio-One) and the absorbance read at 470,652, 665, and $750 \mathrm{~nm}$. Chlorophyll $a$ and $b$ contents were calculated according to Tran et al. (2018).

Effects of thermal stress on biochemical parameters were studied over time (Figure 2B) by measuring changes in the total protein content (Elavarthi and Martin, 2010). For these measurements, $50 \mathrm{mg}$ of the fourth youngest leaves were ground thoroughly to a fine powder using stainless steel beads (SSB32, Next Advance) in a $1.5 \mathrm{~mL}$ Eppendorf Safe-Lock Tube in a Bullet Blender tissue homogenizer (Next Advance). A volume of $0.5 \mathrm{~mL}$ of $0.2 \mathrm{M}$ potassium phosphate buffer ( $\mathrm{pH} 7.8$; Carlo Erba reagents) containing $0.1 \mathrm{mM}$ Ethylenediaminetetraacetic acid (EDTA, Sigma-Aldrich), 0.5\% (w/v) Polyvinylpyrrolidone (PVPP, Sigma-Aldrich), and $1 \%$ Protease inhibitor cocktail (SigmaAldrich) to neutralize phenol effect (Zhang et al., 2007) were added to the sample. The tube then was centrifuged at $13,500 \mathrm{~g}$ at $4^{\circ} \mathrm{C}$ for $20 \mathrm{~min}$, and an approximately $800 \mu \mathrm{L}$ of the supernatant was transferred to a new $1.5 \mathrm{~mL}$ reaction tube (Greiner Bio-One) and stored at $4^{\circ} \mathrm{C}$ until being used for measuring protein content. Total protein contents were determined using the Bradford assay (Bradford, 1976) adapted for microplate readers using bovine serum albumin (BSA, Sigma-Aldrich) as the protein standard according to Tran et al. (2018).

\section{Photosynthetic Functionality}

The photophysiological effects of the heat wave treatment were assessed by measuring the effective quantum yield of photosystem II (PSII) measured as $\Delta \mathrm{F} / F_{m}^{\prime}=\left(F_{m}^{\prime}-\mathrm{F} / \mathrm{F}_{m}\right)$ using pulse amplitude-modulated (PAM) chlorophyll fluorometer (Diving-PAM, Walz, Germany) as commonly applied in many previous studies (Ralph and Gademann, 2005; Saroussi and Beer, 2007; Winters et al., 2011). All PAM measurements were made midday, and taken underwater using the leaf distance clip on the base of the $2^{\text {nd }}$ youngest leaf ( $n=5$ randomly chosen shoots at each time point from each population and treatment) and after removal of epiphytes. Irradiance levels at this position ranged between 130 and $150 \mu \mathrm{mol}$ photons $\mathrm{m}^{-2} \mathrm{~s}^{-1}$ (measured with the micro quantum sensor, Apogee, United States).

\section{Sampling for RNA, RNA Preparation, Primer Design, and Quantitative Real-Time PCR (qRT-PCR) Assays}

Fully mature leaves ( $2^{\text {nd }}$ youngest shoot; approximately 50-100 mg fresh weight) from each biological replicate were randomly collected on day 21, after 2 weeks of exposure to the heat-stress (T3), and day 28, at the end of the experiment (T4), $24 \mathrm{~h}$ after temperatures had returned to the control temperature $\left(26^{\circ} \mathrm{C}\right)$ (Figure 2B). Samples were quickly cleaned from epiphytes and blotted dry using tissue paper, inserted into $1.5 \mathrm{~mL}$ Eppendorf Safe-Lock Tubes, and snap frozen immediately in liquid nitrogen before being stored in $-80^{\circ} \mathrm{C}$ until extraction of RNA.

Total RNA was isolated from young fully mature leaves of $H$. stipulacea control $\left(26^{\circ} \mathrm{C}\right)$ and heat treated $(29$ and $32^{\circ} \mathrm{C}$ ) plant samples using the TRIzol method (2M guanidine thiocyanate, $4 \mathrm{M}$ ammonium thiocyanate, $3 \mathrm{M}$ sodium acetate, 
38\% phenol, 5\% glycerol) (Kant et al., 2006). The total RNA quantity and quality were assessed with a NanoDrop spectrophotometer (ND-1000; NanoDrop Technologies) and its integrity was checked by running on a $1 \%$ agarose gel electrophoresis. Extracted total RNA was then treated with RNase-free DNase I (EN0525, Thermo Fisher Scientific) to eliminate genomic DNA. cDNA was synthesized from $1 \mu \mathrm{g}$ of DNase I treated total RNA using the High-Capacity cDNA Reverse Transcription Kit (Catalog no. 4368813, Applied Biosystems) according to the manufacturer's instructions. The resulting CDNA was diluted 1:10 prior to quantitative real-time PCR (qRT-PCR) assays.

The expression of heat shock protein 70 (Hsp70), Superoxidase dismutase [Mn] (SOD), Photosystem II protein D1 (PsbA), and Photosystem II protein D2 (PsbD) genes were analyzed by qRT-PCR. The gene-specific primer pairs for Hsp70 and UBQ (Ubiquitin - Reference gene) were designed with Primer Express v2.0 (Applied Biosystems, United States) using the recently sequenced and annotated H. stipulacea transcriptome (Oscar et al., unpublished data). Ubiquitin has commonly been used in seagrass studies as a reference gene and has been shown to be stable in a several seagrass species exposed to different salinity, $\mathrm{pH}$, light, and thermal conditions (Serra et al., 2012; Marín-Guirao et al., 2016). Primer sequences for SOD were taken from Winters et al. (2011), while primer sequences for PsbA and PsbD were taken from Marín-Guirao et al. (2016) (see Table 1 for primer sequences).

Real-time PCR was performed with the ABI PRISM 7500 Sequence Detection System (SDS, Applied Biosystems) using SYBR Green to monitor double-stranded DNA (dsDNA) synthesis. Each reaction contained $5 \mu$ l PerfeCTa SYBR Green FastMix (Quanta Biosciences), $4 \mu \mathrm{l}$ (20 ng) cDNA and $300 \mathrm{nM}$ of gene-specific primer in a final volume of $10 \mu \mathrm{l}$. PCR amplifications were performed using the following conditions: $95^{\circ} \mathrm{C}$ for $30 \mathrm{~s}, 40$ cycles of $95^{\circ} \mathrm{C}$ for $5 \mathrm{~s}$ (denaturation) and $60^{\circ} \mathrm{C}$ for $35 \mathrm{~s}$ (annealing/extension). Data were analyzed using the SDS 1.3.1 software (Applied Biosystems). To check the specificity of annealing of the primers, dissociation kinetics was performed at the end of each PCR run. The experiment was performed with three biological replicates and each reaction was performed in triplicates. The relative quantification values for each target gene were calculated by the $2^{-\Delta \Delta C T}$ method (Livak and Schmittgen, 2001) using the Ubiquitin gene as an internal reference (Serra et al., 2012; MarínGuirao et al., 2016). To ensure the validity of the $2^{-\Delta \Delta C T}$ method, twofold serial dilutions of cDNA were used to create standard curves. The amplification efficiency $(E)$ values of the target and reference genes were shown to be approximately equal, with all $E>0.91$, and all linear fit $R^{2}>0.95$ (Livak and Schmittgen, 2001).

\section{Statistical Analysis}

For plant performance, biochemical and photosynthetic functionality measurements, results from within each tank (biological replicates) were averaged and considered as one experimental replicate. In total, 5 experimental replicates ( $n=5$ aquaria) from each of these measurements were used for statistical analyses. For gene expression results, three experimental replicates $(n=3)$ were used to statistically determine the effects of treatments within each gene at each time-point.

GLM (general linear model)-repeated measures analyses were conducted on plant performance, biochemical and photosynthetic functionality results from each population separately using the statistical package IBM SPSS Statistics (v. 20) to test the overall effects of different temperatures (control $26^{\circ} \mathrm{C}$, treatment $29^{\circ} \mathrm{C}$, and treatment $32^{\circ} \mathrm{C}$ ). Normality of data was tested using the Shapiro-Wilk test and homogeneity of variances were verified using Levene's (1960). When parametric assumptions were not met, data were transformed using the Johnson transformation (Johnson, 1949) by using the statistical analysis package SPC for Excel (BPI Consulting, LLC, v.5). Whenever a significant difference was detected, Tukey HSD's multiple comparison post hoc test was applied.

Effects of different experimental temperatures on each gene of interest (GOI) were analyzed separately for each population at each time-point using Pair-wise comparison test with Permutational Multivariate Analyses of Variance (PERMANOVAs) with Primer 6 v.6.1.16 and

TABLE 1 | Primer pairs used in Halophila stipulacea quantitative real-time PCR assays.

\begin{tabular}{|c|c|c|c|c|}
\hline Gene name & Symbol & Function & Primer sequence & References \\
\hline \multirow[t]{2}{*}{ Ubiquitin } & Ubi & Protein degradation (Housekeeping gene) & F 5'-CCTTGGTTCCAGAAATAGC-3' & Present study \\
\hline & & & R 5'-GTTCAACCCATGGCATAC-3' & \\
\hline \multirow[t]{2}{*}{ Heat shock protein 70} & Hsp70 & Molecular chaperone & F 5'-ACCCTTATGACCGATGAG-3' & \\
\hline & & & R 5'-CAGCCTGGTTCTITGTATC-3' & \\
\hline \multirow[t]{2}{*}{ Superoxidase dismutase [Mn] } & SOD & Antioxidant & F 5'-ATGGGTGTGGCTTGCTTA-3' & Winters et al., 2011 \\
\hline & & & R 5'-ATGCATGCTCCCATACATCT-3' & \\
\hline \multirow[t]{2}{*}{ Photosystem II protein D1 } & Psb A & The reaction center protein in PSII & F 5'-GACTGCAATITAGAGAGACGC-3' & Marín-Guirao et al., 2016 \\
\hline & & & R 5'-CAGAAGTTGCAGTCAATAAGGTAG-3' & \\
\hline \multirow[t]{2}{*}{ Photosystem II protein D2 } & Psb D & The reaction center protein in PS II & F 5'-CCGCTITTGGTCACAAATCT-3' & \\
\hline & & & R 5' -CGGATITCCTGCGAAACGAA-3' & \\
\hline
\end{tabular}

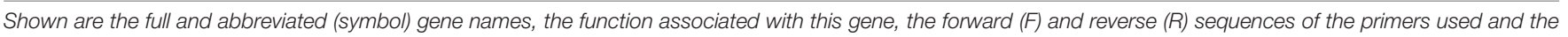
reference from which this primer sequence was taken from. 
PERMANOVA + v.1.0.6 software package (PRIMER-E, Ltd.) (Anderson et al., 2008).

\section{RESULTS}

\section{Environmental Conditions at the Two Sites}

Comparisons between the long-term environmental conditions at the two sites that were based the Bio-ORACLE global dataset (Supplementary materials S1) demonstrated that salinity was very similar between the sites, with an annual average of 39.2 and 38.8 [Practical Salinity Scale (PSS)] for Cyprus and GoA sites, respectively (results not shown). Differences in minimal and maximal water salinity between the sites were even smaller (data not shown).

Long-term (1982-2017) analysis of daily SSTs from both sampled locations showed similar patterns in summer maxima. In both sites, highest temperatures were observed during August, with average water temperatures in August reaching $26.92 \pm 0.02^{\circ} \mathrm{C} \mathrm{SE}$ in Cyprus and $27.41 \pm 0.02^{\circ} \mathrm{C} \mathrm{SE}$ in the northern GoA (Figures 3A,B). During February, the coldest month in both locations, differences were much larger, with average water temperatures in Cyprus reaching $16.61 \pm 0.01^{\circ} \mathrm{C}$
SE, while in the subtropical GoA, February temperatures did not go below $21.27 \pm 0.01^{\circ} \mathrm{C} \mathrm{SE}$ (Figures 3A,B).

In both sites, average warming rates over the multi-decade were significantly positive (regression analysis, $p<0.05$ ), indicating that sea surface warming is taking place, but with some clear differences between the sites (Figures 3C,D). While in Cyprus both winter (February) and summer (August) warming trends were very similar $\left(0.31 \pm 0.17^{\circ} \mathrm{C}\right.$ $\mathrm{SE} /$ decade and $0.32 \pm 0.11^{\circ} \mathrm{C}$ SE/decade, $p<0.05$, respectively; Figure 3D), in GoA August warming was more than double of that observed in February $\left(0.46 \pm 0.18^{\circ} \mathrm{C} \mathrm{SE} /\right.$ decade and $0.21 \pm 0.15^{\circ} \mathrm{C} \mathrm{SE} /$ decade, $p<0.05$, respectively; Figure $3 \mathrm{C}$ ). Seasonally detrended SST regression analysis continued to show that both sites have been warming significantly, although this data shows that warming has been faster in Cyprus $\left(0.36 \pm 0.06^{\circ} \mathrm{C} \mathrm{SE} /\right.$ decade, $\left.p<0.05\right)$ compared with the northern GoA) $0.26 \pm 0.06^{\circ} \mathrm{C} \mathrm{SE} /$ decade, $p<0.05$ ) (Figures 3E,F).

\section{Plant Performance}

Results from the number of shoots throughout the experiment (Figures 4A,B) demonstrate the negative effects of increased water temperature on both native and invasive plants. Native plants suffered massive reductions in shoot number (Figure 4A) resulting in a significant difference between control plants and

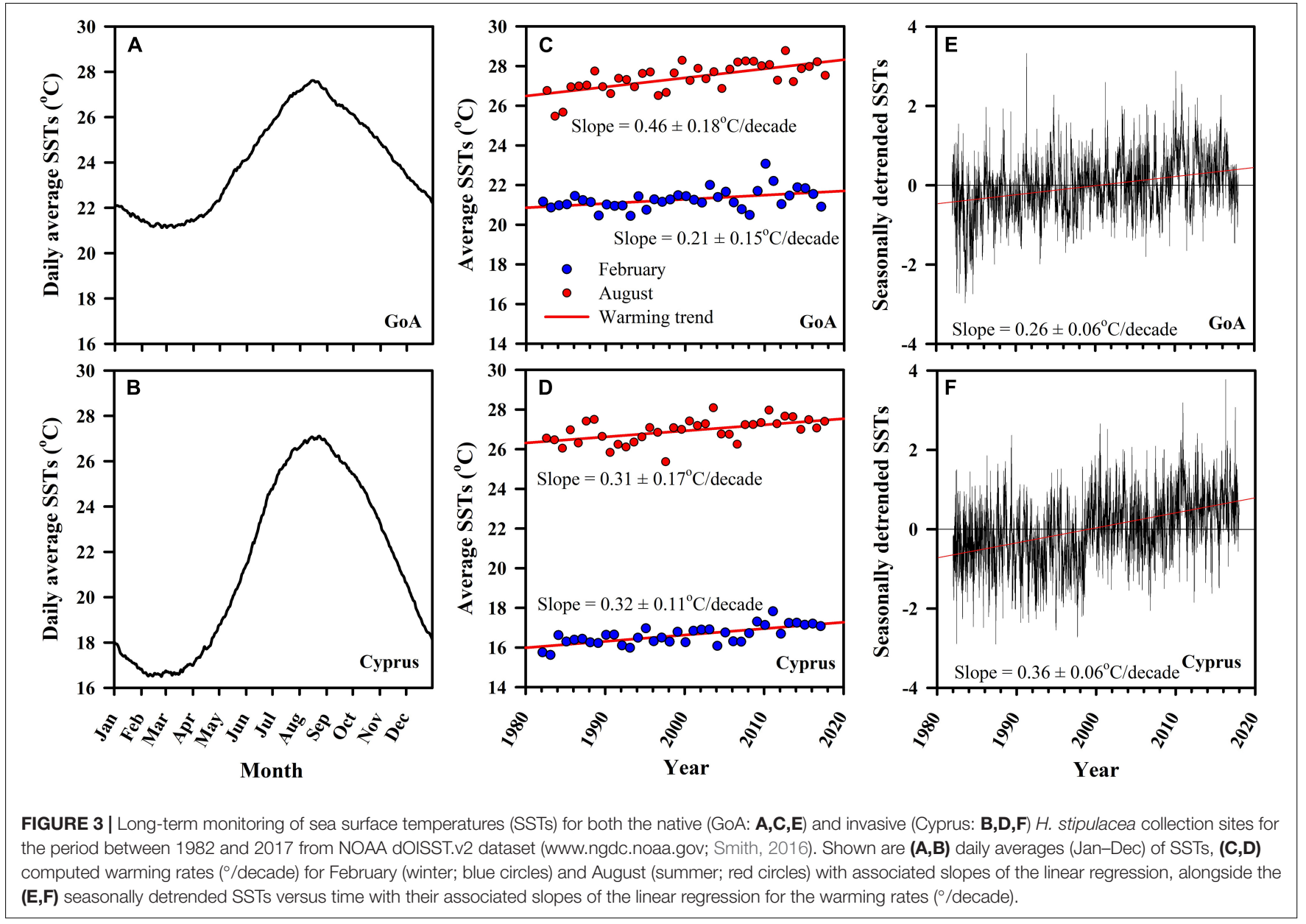



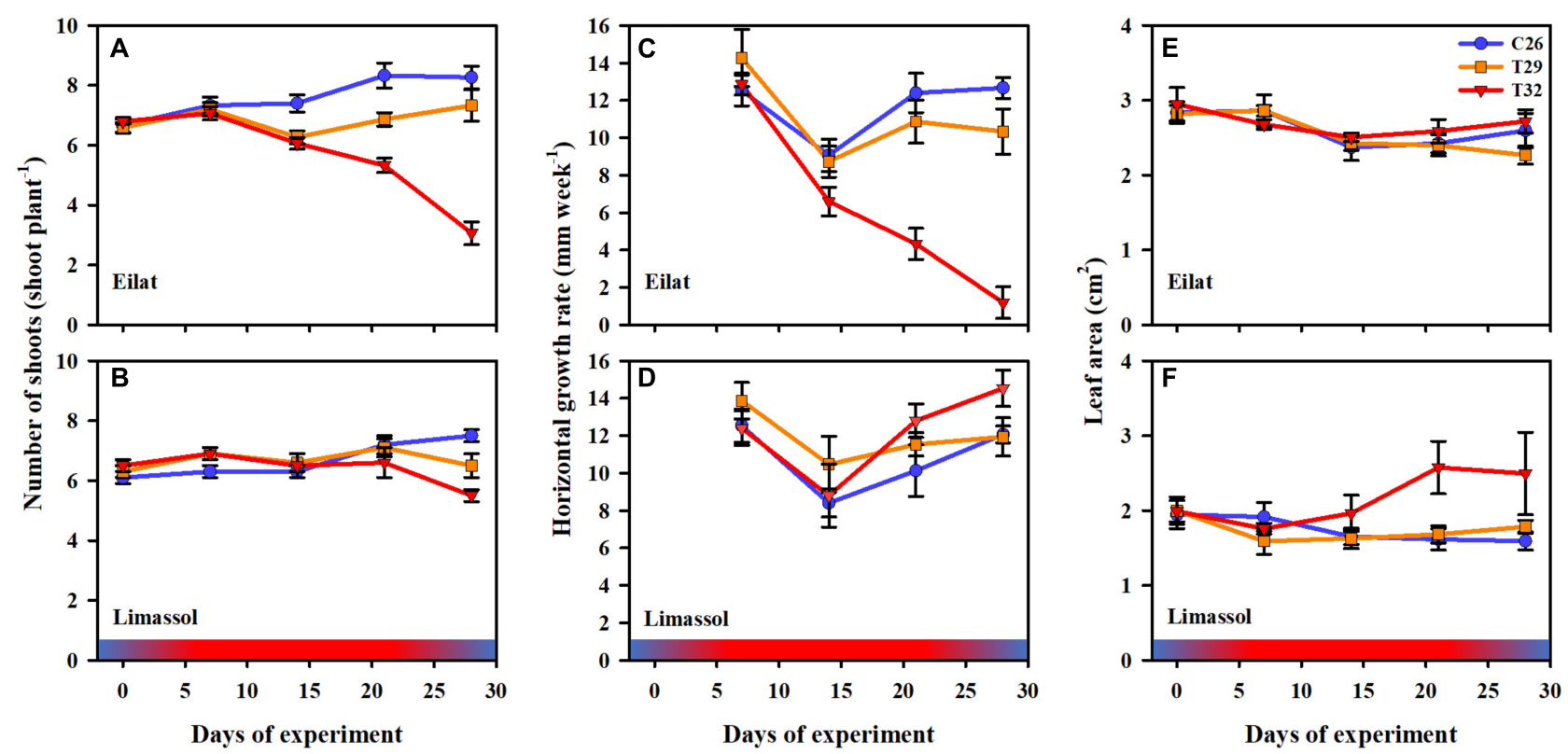

FIGURE 4 | Effects of a simulated heat wave on plant performance of native (A,C,E) vs. invasive (B,D,F) populations of $H$. stipulacea. Shown are changes over time

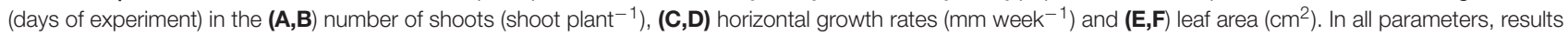
represent $n=5$, mean \pm SE. Gradient color bars indicate the experimental heat wave.

TABLE 2 | GLM-repeated measures analyses and Multiple comparisons with Tukey HSD post hoc results from different populations (Eilat vs. Limassol).

\begin{tabular}{|c|c|c|c|c|c|c|}
\hline Population & Measurements & df & $\boldsymbol{F}$ & $p$ & Post hoc & Multiple comparisons \\
\hline Eilat & Chl $a$ and $b$ & 2 & 10.992 & $\underline{0.002}$ & Tukey HSD & $\mathrm{C} 26=\mathrm{T} 29 \neq \mathrm{T} 32$ \\
\hline Limassol & Chl $a$ and $b$ & 2 & 1.406 & 0.283 & Tukey HSD & $\mathrm{C} 26=\mathrm{T} 29=\mathrm{T} 32$ \\
\hline Eilat & Protein & 2 & 1.478 & 0.267 & Tukey HSD & $\mathrm{C} 26=\mathrm{T} 29=\mathrm{T} 32$ \\
\hline Limassol & Protein & 2 & 15.337 & 0.000 & Tukey HSD & $\mathrm{C} 26=\mathrm{T} 29 \neq \mathrm{T} 32$ \\
\hline Eilat & Number of shoots & 2 & 24.567 & $\underline{0.000}$ & Tukey HSD & $\mathrm{C} 26 \neq \mathrm{T} 29 \neq \mathrm{T} 32$ \\
\hline Limassol & Number of shoots & 2 & 0.828 & 0.460 & Tukey HSD & $\mathrm{C} 26=\mathrm{T} 29=\mathrm{T} 32$ \\
\hline Eilat & Horizontal growth & 2 & 31.386 & 0.000 & Tukey HSD & $\mathrm{C} 26=\mathrm{T} 29 \neq \mathrm{T} 32$ \\
\hline Limassol & Horizontal growth & 2 & 1.107 & 0.362 & Tukey HSD & $\mathrm{C} 26=\mathrm{T} 29=\mathrm{T} 32$ \\
\hline Eilat & Leaf area & 2 & 1.402 & 0.284 & Tukey HSD & $\mathrm{C} 26=\mathrm{T} 29=\mathrm{T} 32$ \\
\hline Limassol & Leaf area & 2 & 5.362 & $\underline{0.022}$ & Tukey HSD & $\mathrm{C} 26=\mathrm{T} 29, \mathrm{C} 26=\mathrm{T} 32, \mathrm{~T} 29 \neq \mathrm{T} 32$ \\
\hline Eilat & $\Delta \mathrm{F} / F_{m}^{\prime}$ & 2 & 20.806 & $\underline{0.000}$ & Tukey HSD & $\mathrm{C} 26=\mathrm{T} 29 \neq \mathrm{T} 32$ \\
\hline Limassol & $\Delta \mathrm{F} / F_{m}^{\prime}$ & 2 & 0.341 & 0.717 & Tukey HSD & $\mathrm{C} 26=\mathrm{T} 29=\mathrm{T} 32$ \\
\hline
\end{tabular}

Significant difference $(p<0.05)$ are in bold and underlined. $n=5$ biological replicates.

heated plants (GLM-repeated measures, $p<0.001$, Table 2). Results from Tukey HSD post hoc multiple comparisons detected significant differences among the three experimental conditions, indicating that exposure to $29^{\circ} \mathrm{C}$ was already warm enough to stress the native plants significantly (C26 $\neq \mathrm{T} 29 \neq \mathrm{T} 32)$. In contrast, while the number of shoots of the invasive plants decreased slightly over time when exposed to thermal stress (Figure 4B), no significant difference was detected with GLM-repeated measures or the Tukey HSD post hoc multiple comparisons, suggesting a higher thermal tolerance level of the invasive plants.

Similarly, increased water temperature seemed to have little or no effect on the growth rates of invasive plants as heated plants were able to maintain their growth rates similar or even slightly higher than growth rates of control plants (Figure 4D), compared with the exposure of the native plants to $32^{\circ} \mathrm{C}$ which dramatically slowed their growth rates (GLM-repeated measures, $p<0.001$, Figure 4C and Table 2). Indeed, even during the recovery phase, native plants that were previously exposed to $32^{\circ} \mathrm{C}$ almost stopped growing (Figure $4 \mathrm{C}$ ). Native plants that were exposed to $29^{\circ} \mathrm{C}$ heated plants, significantly reduced their number of shoots, but this reduction was much less than in the $32^{\circ} \mathrm{C}$ treatment (Figure 4C).

Results from the measurements of leaf surface area show big differences in the response to the increased water temperature. The fact that native leaves start bigger than their invasive counterparts corresponds to them being larger year-round also in the field (Nguyen et al., in review). In native 
plants, no significant difference among treatments were found (Table 2). However, in the invasive plants, extreme increased water temperature of $32^{\circ} \mathrm{C}$, surprisingly caused increases to their leaf sizes (Figure 4F). Indeed, significantly larger leaves were observed in $32^{\circ} \mathrm{C}$ heated invasive plants (GLM-repeated measures, $p=0.022$ and Tukey HSD post hoc Multiple comparisons: $\mathrm{C} 26=\mathrm{T} 29, \mathrm{C} 26=\mathrm{T} 32, \mathrm{~T} 29 \neq \mathrm{T} 32$, Table 2 ). This phenomenon is actually in correspondence with the growth rate results (Figure 4D) strengthening the hypothesis about a higher thermal tolerance of the invasive plants in comparison to their native counterparts.

\section{Biochemistry}

Chlorophyll $a$ and $b$ contents were similar in the two populations at the beginning of the experiment (T0, approximately $0.28 \mathrm{mg}$ $\mathrm{g} \mathrm{FW}^{-1}$; Figures 5A,B). Results (Figure 5) demonstrate that the $29^{\circ} \mathrm{C}$ heated plants (native and invasive) maintained their biochemical contents (i.e., chlorophyll $a$, chlorophyll $b$ and proteins) similar to their control plants. Indeed, in both populations, the GLM-repeated measures and Tukey HSD post hoc multiple comparisons (Table 2) showed no differences between the chlorophyll $a$, chlorophyll $b$ and proteins contents of control vs. $29^{\circ} \mathrm{C}$ treatment (C26 = T29, Table 2).

On the other hand, the responses of native and invasive plants to the $32^{\circ} \mathrm{C}$ warming scenario showed big differences from $\mathrm{T} 2$ onwards (Figures 5A,B). While under stress of $32^{\circ} \mathrm{C}$ chlorophyll $a$ and $b$ contents degraded significantly in the native plants (from 0.28 to $0.20 \mathrm{mg} \mathrm{g} \mathrm{FW}^{-1}$, Figure 5A; GLM-repeated measures $p=0.002$, Tukey HSD post hoc multiple comparisons C26 = T29 $\neq$ T32, Table 2), in the invasive plants, chlorophyll $a$ and $b$ content increased (from 0.23 to $0.50 \mathrm{mg} \mathrm{g} \mathrm{FW}^{-1}$, Figure 5B), but this increase was found to be non-significant (GLM-repeated measures $p=0.283$, Tukey HSD post hoc multiple comparisons C26 = T29 = T32, Table 2).

A similar result was evident from the protein contents (Figures 5C,D). In the native plants, there was a strong trend of reduction in protein content of plants exposed to the $32^{\circ} \mathrm{C}$ warming scenario (GLM-repeated measures, $p=0.267$, Tukey HSD post hoc multiple comparisons, C26 = T29 = T32, Table 2), indicating a possible thermal threshold response.

In contrast, compared to 26 and $29^{\circ} \mathrm{C}$ treatments, plants from the Mediterranean actually increased significantly their protein contents over time when exposed to the $32^{\circ} \mathrm{C}$ warming scenario (GLM-repeated measures, $p<0.001$, Tukey HSD post hoc multiple comparisons, T26 = T29 $\neq$ T32, Figure 5D and Table 2).

\section{Photosynthetic Functionality}

In terms of photosynthetic functionality, results demonstrate differences between the response of native and invasive populations of $H$. stipulacea to the extreme thermal stress. At first, as observed in both populations, increased water temperature

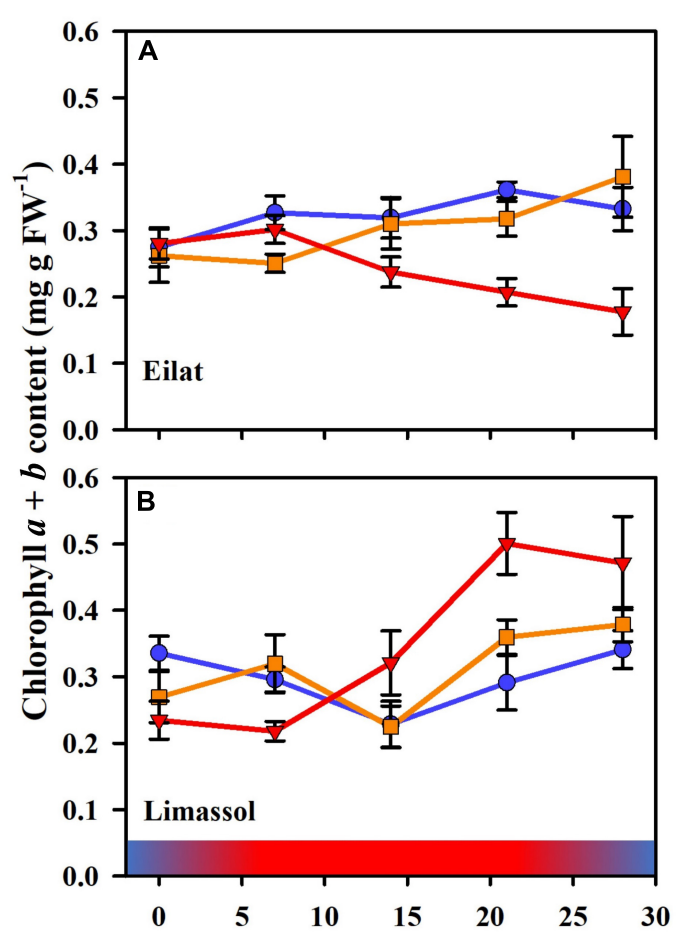

Days of experiment

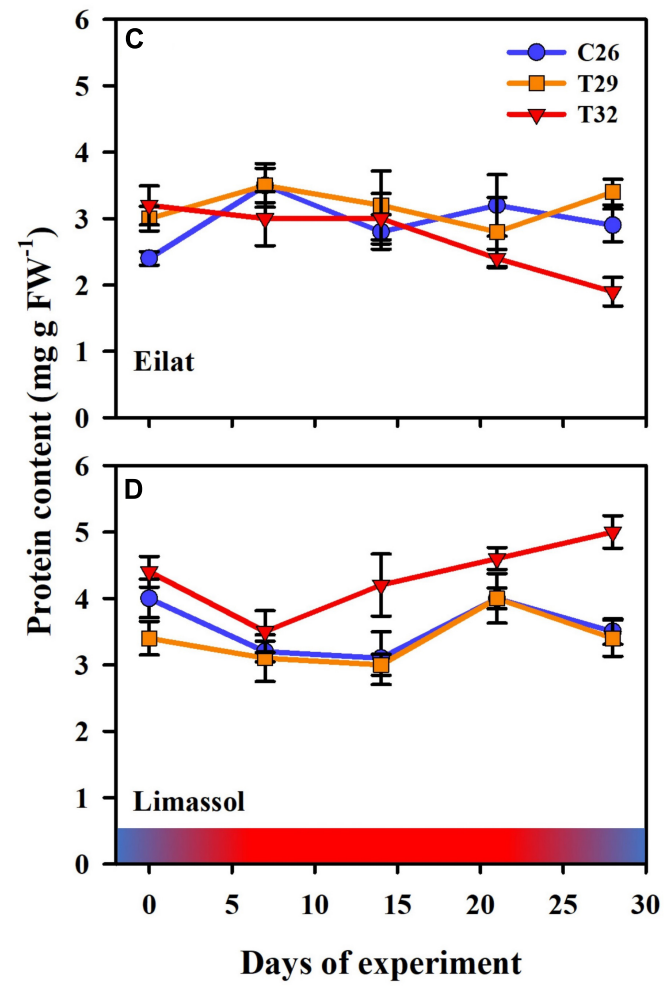

Days of experiment

FIGURE 5 | Effects of a simulated heat wave on plant biochemical indicators of native (A,C) vs. invasive (B,D) populations of $H$. stipulacea. Shown are changes over time (days of the experiment) in the $(\mathbf{A}, \mathbf{B})$ chlorophyll $a$ and $b$, and $\mathbf{( C , D )}$ protein contents. In all parameters, results represent $n=5$, mean \pm SE. Gradient color bars indicate the experimental heat wave. 


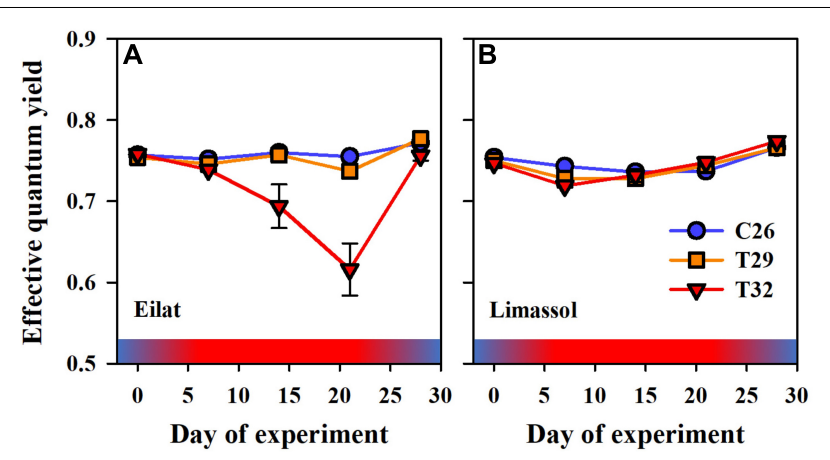

FIGURE 6 | Effects of a simulated heat wave on plant photosynthetic functionality of native (A) vs. invasive (B) populations of $H$. stipulacea. Shown are changes over time (days of experiment) in the effective quantum yield $\Delta F / F_{m}^{\prime}$. In all parameters, results represent $n=5$, mean \pm SE. Gradient color bars indicate the experimental heat wave.

to $29^{\circ} \mathrm{C}$ did not result in any significant difference between heated plants in comparison to control ones (Figures 6A,B). Interestingly, while the extreme thermal condition (i.e., $32^{\circ} \mathrm{C}$ ) lowered significantly the effective quantum yield in native plants (Figure 6A, GLM-repeated measures, $p<0.001$, Tukey HSD post hoc multiple comparisons, T26 = T29 $\neq$ T32, Table 2), oppositely it had no negative effect on the invasive plants (Figure 6B). This contrasting phenomenon suggests a clear difference in thermal tolerance between the two populations.

\section{Gene Expression}

Gene expression results from this study provide the very first insight into some of the molecular responses of $H$. stipulacea to thermal stress. Results include the expression of three different gene categories including a molecular chaperone that is expressed in response to stress (HSP70), photosynthesis related-genes (psbD and psbA) and an antioxidant related-gene (SOD; Figure 7).

All studied genes were significantly influenced by population, treatment or their interactions (Table 3). Overall, expression patterns were lower under moderate stress $\left(29^{\circ} \mathrm{C}\right)$ as compared to the more severe thermal stress of $32^{\circ} \mathrm{C}$ (Figure 7). Native plants expressed significantly more HSP70 during the stressful condition (T3) both at $29^{\circ} \mathrm{C}$ and significantly more at $32^{\circ} \mathrm{C}$ (Figure 7A), compared with the invasive plants where exposure to both temperatures did not cause a significant upregulation of HSP70 (Figure 7C). Returning plants from both populations to control temperatures at $\mathrm{T} 4$ entailed a shift to down-regulation of HSP70, with plants previously exposed to $32^{\circ} \mathrm{C}$ having significantly stronger down-regulation compared with control plants (Figures 7A,C; Pair-wise comparison, $p<0.001$, Table 3). Down-regulation of plants previously exposed to $32^{\circ} \mathrm{C}$ was stronger in native compared with invasive plants (Figures $7 \mathbf{B}, \mathbf{D}$ ).

During the heat stress condition (T3), both native and invasive plants showed up-regulation of psbD and down-regulation of psbA (Figures 7A,C). The up-regulation of psbD was significant only for the invasive plants (Figures 7A,B, Pair-wise comparison, $p<0.001$, Table 3). When water temperatures returned to the control level (Figures 7B,D), the $32^{\circ} \mathrm{C}$ invasive heatedplants shifted their expression from a very weak down-regulation during the heat stress itself, to a significant upregulation of psbA (Figure 7D, Pair-wise comparison, $p<0.001$, Table 3). No change was found in the expression pattern of the native plants (Figure 7B).

Lastly, thermal-induced expression of the antioxidant-related gene (SOD) concurs with other genes showing the invasive plants were more responsive to increased water temperature. Both native and invasive plants significantly up-regulated SOD to compensate with the increased damage caused by thermal stress (Figures 7A,C), with a much stronger up-regulation found for the invasive population. Returning plants to control water temperatures (T4) resulted in reversing the upregulation of SOD found during the heat wave (T3, Figures 7A,C) to a significant down-regulation during of SOD in T4 (Figures 7B,D). In both populations, there was a stronger down-regulation of SOD during T4 in plants that were previously exposed to the higher temperatures $\left(32^{\circ} \mathrm{C}\right)$. The fact that this downregulation of SOD was only significant in the invasive plants (Figure 7D) indicates that the invasive plants might be more thermally plastic than the native ones.

\section{DISCUSSION}

Invasiveness of plants may be accompanied by rapid evolution due to selection in the colonized habitat (examples from land plants - Maron et al., 2004; Novy et al., 2013; Sultan et al., 2013). Here we demonstrate that plants of invasive seagrass population may have undergone an additional adaptation to the changes in the colonized habitat. Plants of $H$. stipulacea from the invasive population performed overall better than plants from the native population in a common garden simulated thermal stress experiment. We show that while native plants were negatively affected in photo-physiological and growth responses by thermal stress, invasive plants did not suffer and might have even benefited from it. We also show that the putative mechanism of adaptation to thermal stress could be the differential gene expression. Taken together, these results hint toward rapid evolution of $H$. stipulacea plants following their Lessepsian migration through the Suez Canal. This process could possibly work through strong selection on the colonizing genotypes during (e.g., the warm the ballast water of ships) or after their transport (post-introduction evolution - through exposure to many heat waves). Such a process would help to maximize the performance and establishment of the invasive population in their new environment (Molina-Montenegro et al., 2018).

Our results support the hypothesis that climate change amplifies the spread of invasive plants (Bradley et al., 2010; Zelikova et al., 2013). The long-term analysis of daily SST concurs with previous studies in the GoA (Fine et al., 2013) and the eastern Mediterranean Sea (Rilov, 2016; Ozer et al., 2017). In both of our studied sites, average SST warming during the last 35 years was higher than the global mean coastal SST trend of $0.17 \pm 0.11^{\circ} \mathrm{C} /$ decade (Liao et al., 2015). In the GoA, the temperature has been warming at a rate 1.63 times faster than 

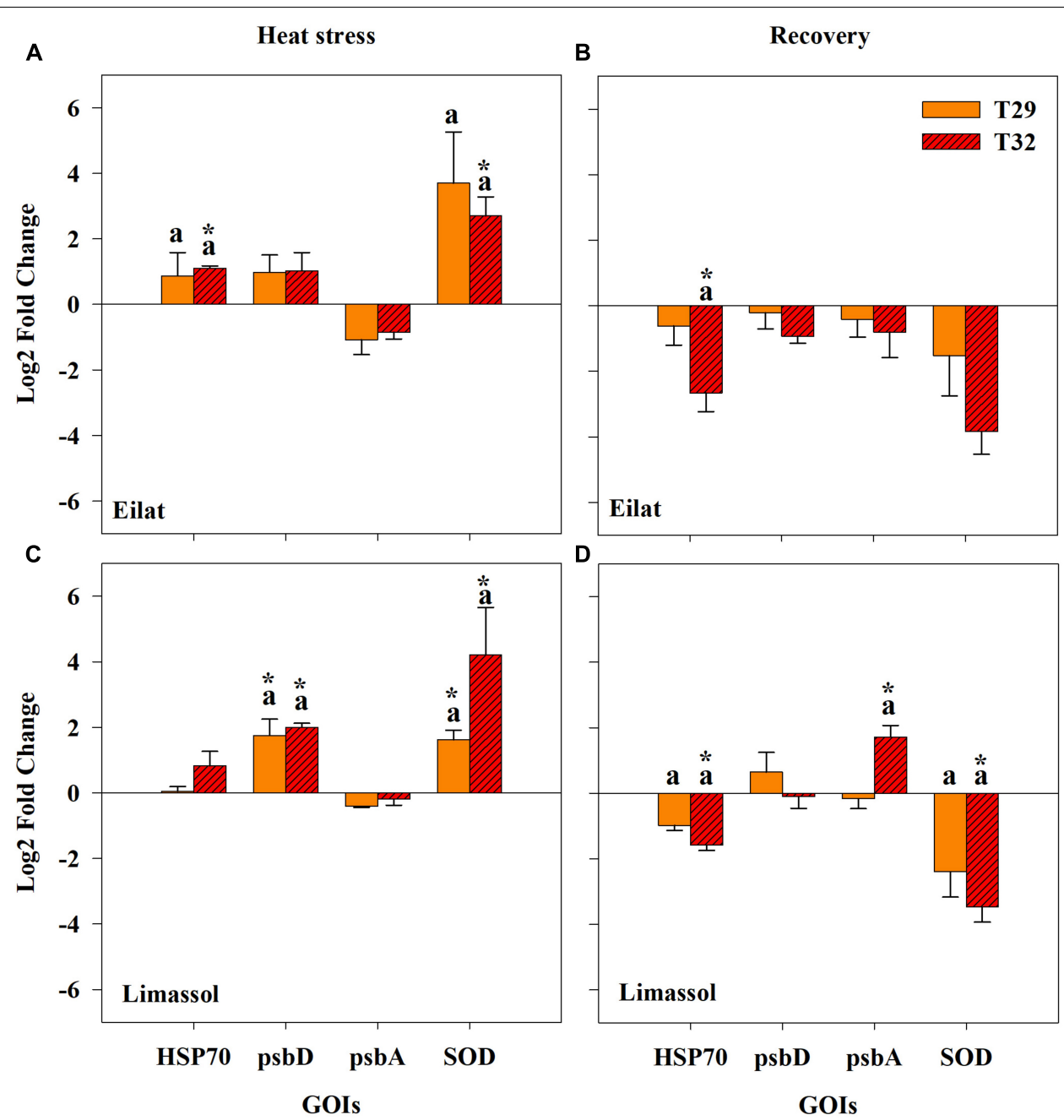

FIGURE 7 | Effects of a simulated heat wave on plant gene expression (log2 scale) in native (A,B) and invasive (C,D) populations of $H$. stipulacea plants $(n=3$; mean \pm SE). Results of pair-wise comparison tests are presented on top of each column: an asterisk $\left({ }^{*}\right)$ indicates significant differences between control vs. heated plants $(p<0.001)$ and letters represent differences between 29 and $32^{\circ} \mathrm{C}$-heated plants. Shown are expression patterns during the middle of the heat stress (T3; A,C) and following $24 \mathrm{~h}$ after the return to the control temperature (T4; B,D). Gene abbreviations are found in Table $\mathbf{1 .}$

this global coastal average, but in Cyprus, warming has been occurring at even faster rates, 2.25 times faster than this global coastal average SST trend.

Under assault for at least a century, seagrasses may be nearing a crisis with respect to global sustainability (Waycott et al., 2009; Hyndes et al., 2016). In addition to increasing mean temperatures (Jordà et al., 2012), seagrass ecosystems will also face increasing climate variability that will affect the frequency, duration and intensity of summer heat waves (Schär et al., 2004; Diez et al., 2012; Oliver et al., 2018), with a projected longer duration of warm periods (Jordà et al., 2012; Oliver et al., 2018). Furthermore, these global climatic changes have been predicted to exacerbate invasions (Buckley and Csergö, 2017).

The results from our microcosm experiment suggest that native and invasive populations of $H$. stipulacea might differ in their evolutionary trajectories under future projections of climate changes. Plants from the native population of GoA showed signs of stress during and after the exposure to high temperatures (i.e., $32^{\circ} \mathrm{C}$ ) in most of the measured parameters: they lost high numbers of shoots per plants (Figure 4A), reduced their growth rates (Figure 4C) and leaf sizes (Figure 4E). The plants from the invasive population of Cyprus, on the other hand, kept the number of shoots constantly (Figure 4B), their growth rates were similar to control plants (Figure 4D), and surprisingly doubled their leaf sizes under the same high temperature of $32^{\circ} \mathrm{C}$; these results concur with those of Georgiou et al. (2016) that also showed increased growth rates of $H$. stipulacea from Cyprus exposed to increased water temperatures. Biochemical assays further suggested that GoA plants suffered at simulated high temperature and could not be able to maintain their chlorophylls as well as their protein contents (Figures $\mathbf{5 A}, \mathbf{C}$ ). In contrast, exposure to thermal stress caused Cyprus plants to increase significantly their photosynthetic pigments and protein (Figures 5B,D and Table 2). Application of PAM fluorometry 
TABLE 3 | Pair-wise comparison results on $\triangle \mathrm{Ct}$ data of genes of interests (GOls).

\begin{tabular}{|c|c|c|c|c|c|c|c|c|c|c|}
\hline \multirow[t]{2}{*}{ Population } & \multirow[t]{2}{*}{ GOI } & \multirow[t]{2}{*}{ Groups } & \multicolumn{3}{|c|}{ T3 } & \multicolumn{3}{|c|}{ T4 } & \multicolumn{2}{|c|}{ Pair-wise comparison } \\
\hline & & & $t$ & $\boldsymbol{p}_{(\text {perm })}$ & $\begin{array}{l}\text { Unique } \\
\text { perms }\end{array}$ & $t$ & $\boldsymbol{p}_{(\text {perm })}$ & $\begin{array}{l}\text { Unique } \\
\text { perms }\end{array}$ & T3 & T4 \\
\hline \multirow[t]{7}{*}{ Eilat } & HSP70 & C26, T29 & 0.96857 & 0.3955 & 10 & 0.35353 & 0.5008 & 10 & $\begin{array}{l}\mathrm{C} 26=\mathrm{T} 29, \mathrm{~T} 29=\mathrm{T} 32, \\
\mathrm{C} 26 \neq \mathrm{T} 32\end{array}$ & $\mathrm{C} 26=\mathrm{T} 29 \neq \mathrm{T} 32$ \\
\hline & & C26, T32 & 2.786 & $\underline{0.0001}$ & 10 & 1.8645 & $\underline{0.0001}$ & 10 & & \\
\hline & & C26, T32 & 1.1073 & 0.4119 & 10 & 1.1669 & 0.3063 & 10 & & \\
\hline & & T29, Т32 & 0.10778 & 0.8018 & 10 & 1.4035 & 0.2912 & 10 & & \\
\hline & Psb A & C26, T29 & 1.574 & 0.1028 & 10 & 0.70632 & 0.7049 & 10 & $\mathrm{C} 26=\mathrm{T} 29=\mathrm{T} 32$ & $\mathrm{C} 26=\mathrm{T} 29=\mathrm{T} 32$ \\
\hline & & C26, Т32 & 1.7734 & 0.0964 & 10 & 0.85223 & 0.507 & 10 & & \\
\hline & & T29, Т32 & 0.56742 & 0.596 & 10 & 0.3809 & 0.9 & 10 & & \\
\hline \multirow[t]{10}{*}{ Limassol } & HSP70 & C26, T29 & 0.3616 & 0.8061 & 10 & 1.1231 & 0.2895 & 10 & $\mathrm{C} 26=\mathrm{T} 29=\mathrm{T} 32$ & $\begin{array}{l}\mathrm{C} 26=\mathrm{T} 29, \mathrm{~T} 29=\mathrm{T} 32, \\
\mathrm{C} 26 \neq \mathrm{T} 32\end{array}$ \\
\hline & & C26, T32 & 1.5214 & 0.2037 & 10 & 1.8723 & $\underline{0.0001}$ & 10 & & \\
\hline & & Т29, Т32 & 1.6395 & 0.0971 & 10 & 2.6359 & 0.1018 & 10 & & \\
\hline & psbD & C26, T29 & 2.0624 & $\underline{0.0001}$ & 10 & 1.0817 & 0.3031 & 10 & $\mathrm{C} 26 \neq \mathrm{T} 29=\mathrm{T} 32$ & $\mathrm{C} 26=\mathrm{T} 29=\mathrm{T} 32$ \\
\hline & & C26, Т32 & 3.1588 & $\underline{0.0001}$ & 10 & 0.2165 & 0.7953 & 10 & & \\
\hline & & Т29, Т32 & 0.65765 & 0.6019 & 10 & 1.0192 & 0.2948 & 10 & & \\
\hline & psbA & C26, T29 & 1.4273 & 0.2965 & 10 & 0.58878 & 0.4973 & 10 & $\mathrm{C} 26=\mathrm{T} 29=\mathrm{T} 32$ & $\mathrm{C} 26=\mathrm{T} 29 \neq \mathrm{T} 32$ \\
\hline & & C26, T32 & 0.47392 & 0.6903 & 10 & 4.2527 & $\underline{0.0001}$ & 10 & & \\
\hline & & T29, Т32 & 1.1579 & 0.3033 & 10 & 3.4207 & $\underline{0.0001}$ & 10 & & \\
\hline & SOD & C26, T29 & 3.0314 & $\underline{0.0001}$ & 10 & 1.0241 & 0.496 & 10 & $\mathrm{C} 26 \neq \mathrm{T} 29=\mathrm{T} 32$ & $\begin{array}{l}\mathrm{C} 26=\mathrm{T} 29, \mathrm{~T} 29=\mathrm{T} 32, \\
\mathrm{C} 26 \neq \mathrm{T} 32\end{array}$ \\
\hline
\end{tabular}

Significant differences $(p<0.05)$ are in bold and underlined.

strengthens our conclusions as significant reduction in $\Delta \mathrm{F} / \mathrm{Fm}^{\prime}$ was only found for native plants (Figure 6).

The results from this study suggest that native and invasive $H$. stipulacea plants might underwent different evolutionary pathways, and potentially will further diverge in their evolutionary trajectory given that the current trends of increased sea temperatures continue. While the plants from the northern GoA suffered greatly from simulated increases in seawater temperatures, the plants from the invasive population from the eastern Mediterranean did not suffer physiologically and seemed to take advantage of simulated seawater warming.

We speculate that if these plants are representative of larger populations, future increase in seawater temperature will threaten the native populations and benefit the invasive ones. Further exploration of this prediction should use multiple populations from both seas, in order to assess the width of the phenomenon found here in representing plants from one site in each sea.

Although It has been suggested that the range of expansion of $H$. stipulacea in the Mediterranean will be limited by the $15^{\circ} \mathrm{C}$ sea surface isotherm experienced during winter seasons (reviewed by Gambi et al., 2009), our results are in agreement with the those of Georgiou et al. (2016) that predicted that the rising winter and summer temperatures in the Mediterranean Sea (Ozer et al., 2017) will not be a limiting factor of the expansion of $H$. stipulacea in the Mediterranean Sea.

The work presented here, alongside that of Georgiou et al. (2016) represent the only two studies that experimentally investigated the effects of temperature on $H$. stipulacea, shedding light on the gap of knowledge in this ecologically important species compared with the numerous published studies on the effects of thermal stress on both temperate and tropical species (Bergmann et al., 2010; Winters et al., 2011; Tutar et al., 2017; George et al., 2018).

Our gene expression results provide some very first molecular knowledge regarding the effects of temperature on $H$. stipulacea. Changes in the expression level of heat shock protein (HSP70) in our study shed light on some of the molecular mechanisms behind the physiological differences in our experimental plants. Increases in expression of HSP70 as a result of thermal stress were also shown in other seagrass species including Zostera marina, Posidonia oceanica, and Cymodocea nodosa (Bergmann et al., 2010; Marín-Guirao et al., 2016). The increase in expression of HSP70 in H. stipulacea plants from the invasive population under 
simulated increased temperature, suggests that invasive plants might have mechanisms in place to cope with sea warming. The significantly higher expression levels of SOD in the invasive population could give these plants the protection from reactive oxygen species (ROS) needed to continue normal photosynthesis under thermal stress (Lesser, 1997; Sharkey, 2005). The fact that psbA (the chloroplast gene that codes for the photosystem II protein D1) tends in both populations to be only weakly down-regulated during the thermal stress, might indicate the possibility that photosystem II was not the main site of damage of the heated plants.

While we did not include genotyping data in this current study, a recent study on reconstructing the invasion history of the $H$. stipulacea applied 2bRAD sequencing to several populations, including the two populations used here (Chiquillo et al., unpublished data). Results from that study clearly demonstrate that genetic diversity in the Mediterranean Sea is actually lower than that in the GoA. The fact that the invasive Cyprus $H$. stipulacea population, with lower genetic diversity, did better under thermal stress than its native GoA higher diversity counterpart (Chiquillo et al., unpublished data), does not concur with those of Ehlers et al. (2008) that showed that Zostera marina populations with higher genotypic diversity survived thermal stress better than populations with reduced genotypic diversity. One possible explanation for this could be a high pre-existing genetic diversity in the native GoA range (as shown by Chiquillo et al., unpublished data) and the later filtering of genotypes that could be locally pre-adapted in the new invasive range to climate change (Molina-Montenegro et al., 2018).

With the recent doubling of Suez Canal (Galil et al., 2015, 2017) and the ongoing tropicalization and warming of the Mediterranean (Bianchi and Morri, 2003; Borghini et al., 2014) a process that is happening even faster in the eastern Mediterranean (Ozer et al., 2017), H. stipulacea could potentially become more prevalent in these waters in the coming years. This prediction is quite probable considering that conditions in the Mediterranean Sea are becoming less favorable for its temperate seagrass species (Jordà et al., 2012; Chefaoui et al., 2018; MarínGuirao et al., 2018; Savva et al., 2018) and more welcoming to tropical species (Sghaier et al., 2014; Georgiou et al., 2016; Gerakaris et al., 2019).

In the Caribbean Sea, H. stipulacea has been demonstrating its negative characteristic by invading the entire Caribbean (Willette and Ambrose, 2009, 2012; Maréchal et al., 2013; Vera et al., 2014; Willette et al., 2014; Steiner and Willette, 2015; van Tussenbroek et al., 2016; Scheibling et al., 2018). Studies in the Caribbean have shown that $H$. stipulacea is physically displacing local Caribbean seagrass species (e.g., Syringodium filiforme, Halophila decipiens, and Halodule wrightii; Willette and Ambrose, 2012), thus changing the Caribbean's seagrass landscape (Steiner and Willette, 2015). Taking into account what is already happening in the Caribbean Sea, combined with our knowledge on the changing Mediterranean Sea (Jordà et al., 2012; Rilov, 2016; Ozer et al., 2017; discussed above), our results presented here demonstrate clearly that the spreading of $H$. stipulacea in the
Mediterranean Sea has a high potential threat to biodiversity of the Mediterranean region.

While the spread of $H$. stipulacea in the Mediterranean Sea is worrying, there is also a threat to the native sub-tropical populations in the GoA. The National Monitoring Program at the Gulf of Eilat (NMP-Israel) has been collecting high-resolution data of local marine ecosystems since $2004^{2}$, but most of this program's efforts have been focused on the coral reefs in the region, while local $H$. stipulacea meadows have only very recently been included in this program.

Results from our study highlight the importance of longterm, coordinated monitoring of this important engineering species, in both native and invasive populations of $H$. stipulacea. It should be noted that we used only one population from each basin. While running simulated thermal stress experiments with multiple temperatures and populations is complicated enough ( 3 temperatures $\times 2$ populations in the present study), including more populations in such experiments would be necessary in the future to account for the genetic variability (Procaccini et al., 1999) and different thermal tolerances that might exist in $H$. stipulacea populations in both the Mediterranean and the Red Sea. Thus, we call for further studies to include multiple populations from each basin to reconfirm the results presented here.

\section{DATA AVAILABILITY STATEMENT}

The datasets generated for this study are available on request to the corresponding author.

\section{AUTHOR CONTRIBUTIONS}

HN, YS, and GW conceived and designed the experiments. HN, NY, and SB performed the experiments. HN and GW analyzed the results. HN, FL, YS, and GW wrote the manuscript. All authors reviewed the manuscript.

\section{ACKNOWLEDGMENTS}

We thank ICA in Israel and the Israeli Ministry for Science and Technology (MOST) for supporting the Dead-Sea \& Arava Science Center (ADSSC) and for supporting the seagrass mesocosm facility. We also thank the Arava International Center for Agriculture Training (AICAT) for giving financial support to HN during his M.Sc. We also thank the Manna Center Program for Food Safety \& Security, at the School of Plant Sciences and Food Security Faculty of Life Sciences Tel Aviv University (TAU) for their ongoing support for the co-op between TAU and ADSSC. We also thank the Blaustein Center for Scientific Cooperation (BCSC) and the PBC Program of Israeli Council for Higher Education for postdoctoral fellowships to NY. FL was funded by FEDER funds through COMPETE (POCI01-0145-FEDER-031088) and by National funds through FCT (PTDC/BIA-BMA/31088/2017).

\footnotetext{
${ }^{2}$ http://www.iui-eilat.ac.il/Research/NMPAbout.aspx
} 


\section{REFERENCES}

Abràmoff, M. D., Magalhães, P. J., and Ram, S. J. (2004). Image processing with ImageJ. Biophotonics Int. 11, 36-42.

Anderson, M. J., Gorley, R. N., and Clarke, K. R. (2008). PERMANOVA+ for PRIMER: Guide to Software and Statistical Methods. Plymouth: PRIMER-E.

Arias-Ortiz, A., Serrano, O., Masqué, P., Lavery, P. S., Mueller, U., Kendrick, G. A., et al. (2018). A marine heatwave drives massive losses from the world's largest seagrass carbon stocks. Nat. Clim. Chang. 8, 1-7. doi: 10.1038/s41558-0180096-y

Assis, J., Tyberghein, L., Bosch, S., Verbruggen, H., Serrão, E. A., and De Clerck, O. (2018). Bio-ORACLE v2.0: extending marine data layers for bioclimatic modelling. Global Ecol. Biogeogr. 27, 277-284. doi: 10.1111/geb.12693

Beca-Carretero, P., Guihéneuf, F., Marín-Guirao, L., Bernardeau-Esteller, J., García-Muñoz, R., Stengel, D. B., et al. (2018). Effects of an experimental heat wave on fatty acid composition in two Mediterranean seagrass species. Mar. Pollut. Bull. 134, 27-37. doi: 10.1016/j.marpolbul.2017.12.057

Beck, M. W., Heck, K. L., Able, K. W., Childers, D. L., Eggleston, D. B., Gillanders, B. M., et al. (2006). The identification, conservation, and management of estuarine and marine nurseries for fish and invertebrates. Bioscience 51, 633-641.

Bergmann, N., Winters, G., Rauch, G., Eizaguirre, C., Gu, J., Nelle, P., et al. (2010). Population-specificity of heat stress gene induction in northern and southern eelgrass Zostera marina populations under simulated global warming. Mol. Ecol. 19, 2870-2883. doi: 10.1111/j.1365-294X.2010.04731.x

Bianchi, C. N., and Morri, C. (2003). Global sea warming and "tropicalization" of the Mediterranean Sea: biogeographic and ecological aspects. Biogeographia 24, 319-327. doi: 10.21426/B6110129

Borghini, M., Bryden, H., Schroeder, K., Sparnocchia, S., and Vetrano, A. (2014). The Mediterranean is getting saltier. Ocean Sci. Discuss. 11, 735-752. doi: 10.5194/osd-11-735-2014

Bradford, M. M. (1976). A rapid and sensitive method for the quantitation of microgram quantities of protein utilizing the principle of protein-dye binding. Anal. Biochem. 72, 248-254. doi: 10.1016/0003-2697(76)90527-3

Bradley, B. A., Blumenthal, D. M., Wilcove, D. S., and Ziska, L. H. (2010). Predicting plant invasions in an era of global change. Trends Ecol. Evol. 25, 310-318. doi: 10.1016/j.tree.2009.12.003

Buckley, Y. M., and Csergö, A. M. (2017). Predicting invasion winners and losers under climate change. Proc. Natl. Acad. Sci. U.S.A. 114, 4040-4041. doi: 10. 1073/pnas.1703510114

Campbell, S. J., McKenzie, L. J., and Kerville, S. P. (2006). Photosynthetic responses of seven tropical seagrasses to elevated seawater temperature. J. Exp. Mar. Bio. Ecol. 330, 455-468. doi: 10.1016/j.jembe.2005.09.017

Chatfield, C. (2016). The Analysis of Time Series: An Introduction. 6th, Revised ed. London: Chapman and Hall/CRC Press.

Chefaoui, R. M., Duarte, C. M., and Serrão, E. A. (2018). Dramatic loss of seagrass habitat under projected climate change in the Mediterranean Sea. Glob. Chang. Biol. 24, 4919-4928. doi: 10.1111/gcb.14401

Chiquillo, K. L., Barber, P. H., and Willette, D. A. (2018). Fruits and flowers of the invasive seagrass Halophila stipulacea in the Caribbean Sea. Bot. Mar. 62, 109-112. doi: 10.1515/bot-2018-0052

Costanza, R., de Groot, R., Sutton, P., van der Ploeg, S., Anderson, S. J., Kubiszewski, I., et al. (2014). Changes in the global value of ecosystem services. Glob. Environ. Chang. 26, 152-158. doi: 10.1016/j.gloenvcha.2014.04.002

Davey, P. A., Pernice, M., Sablok, G., Larkum, A., Lee, H. T., Golicz, A., et al. (2016). The emergence of molecular profiling and omics techniques in seagrass biology; furthering our understanding of seagrasses. Funct. Integr. Genomics 16, 465-480. doi: 10.1007/s10142-016-0501-4

den Hartog, C. (1970). Sea-Grasses of the World. Amsterdam: North-Holland Publication Co.

den Hartog, C. (1972). Range extension of Halophila stipulacea (Hydrocharitaceae) in the Mediterranean. Blumea Biodivers. Evol. Biogeogr. Plants 20, $154-156$.

Diez, J. M., D’Antonio, C. M., Dukes, J. S., Grosholz, E. D., Olden, J. D., Sorte, C. J. B., et al. (2012). Will extreme climatic events facilitate biological invasions? Front. Ecol. Environ. 10, 249-257. doi: 10.1890/110137

Easterling, D. R., Meehl, G. A., Parmesan, C., Changnon, S. A., Karl, T. R., and Mearns, L. O. (2000). Climate extremes: observations, modeling, and impacts. Science 289, 2068-2074. doi: 10.1126/science.289.5487.2068
Ehlers, A., Worm, B., and Reusch, T. B. H. (2008). Importance of genetic diversity in eelgrass Zostera marina for its resilience to global warming. Mar. Ecol. Prog. Ser. 355, 1-7. doi: 10.3354/meps07369

El Shaffai, A. (2011). Field Guide to Seagrasses of the Red Sea. Gland: IUCN.

Elavarthi, S., and Martin, B. (2010). Spectrophotometric assays for antioxidant enzymes in plants. Methods Mol. Biol. 639, 273-280. doi: 10.1007/978-1-60761702-0_16

Fine, M., Gildor, H., and Genin, A. (2013). A coral reef refuge in the Red Sea. Glob. Chang. Biol. 19, 3640-3647. doi: 10.1111/gcb.12356

Foster, G., and Rahmstorf, S. (2011). Global temperature evolution 1979-2010. Environ. Res. Lett. 6, 44022.

Fourqurean, J. W., Duarte, C. M., Kennedy, H., Marbà, N., Holmer, M., Mateo, M. A., et al. (2012). Seagrass ecosystems as a globally significant carbon stock. Nat. Geosci. 5, 505-509. doi: 10.1002/eap.1489

Galil, B., Marchini, A., Occhipinti-Ambrogi, A., and Ojaveer, H. (2017). The enlargement of the Suez Canal-Erythraean introductions and management challenges. Manag. Biol. Invasions 8, 141-152. doi: 10.3391/mbi.2017. 8.2.02

Galil, B. S., Boero, F., Campbell, M. L., Carlton, J. T., Cook, E., Fraschetti, S., et al. (2015). 'Double trouble': the expansion of the Suez Canal and marine bioinvasions in the Mediterranean Sea. Biol. Invasions 17, 973-976. doi: 10. 1111/j.1749-4877.2012.00307.x

Gambi, M. C., Barbieri, F., and Bianchi, C. N. (2009). New record of the alien seagrass Halophila stipulacea (Hydrocharitaceae) in the western Mediterranean: a further clue to changing Mediterranean Sea biogeography. Mar. Biodivers. Rec. 2:e84. doi: 10.1017/s175526720900058x

Gambi, M. C., Gaglioti, M., and Barbieri, F. (2018). Sometimes they come back: the re-colonization of the alien seagrass Halophila stipulacea (Forsskål) Ascherson, 1867 (Hydrocharitaceae) in the Palinuro Harbor (Tyrrhenian Sea, Italy). BioInv. Rec. 7, 215-221. doi: 10.3391/bir.2018.7.3.01

Genin, A., Lazar, B., and Brenner, S. (1995). Vertical mixing and coral death in the Red Sea following the eruption of Mount Pinatubo. Nature 377, 507-510. doi: $10.1038 / 377507 \mathrm{a} 0$

George, R., Gullström, M., Mangora, M. M., Mtolera, M. S. P., and Björk, M. (2018). High midday temperature stress has stronger effects on biomass than on photosynthesis: a mesocosm experiment on four tropical seagrass species. Ecol. Evol. 8, 4508-4517. doi: 10.1002/ece3.3952

Georgiou, D., Alexandre, A., Luis, J., and Santos, R. (2016). Temperature is not a limiting factor for the expansion of Halophila stipulacea throughout the Mediterranean Sea. Mar. Ecol. Prog. Ser. 544, 159-167. doi: 10.3354/meps 11582

Gerakaris, V., Polytimi-loli, L., and Issaris, Y. (2019). First record of the tropical seagrass species Halophila decipiens ostenfeld in the Mediterranean Sea. Aquat. Bot. 160:103151. doi: 10.1016/j.aquabot.2019.103151

Green, E. P., and Short, F. T. (2003). World Atlas of Seagrasses. Cambridge: World Conservation Monitoring Centre.

Hector, R., and David, L. B. (2004). Occurrence of the seagrass Halophila stipulacea in the tropical West Atlantic. Bull. Mar. Sci. 75, 131-135.

Hoegh-Guldberg, O., Mumby, P. J., Hooten, A. J., Steneck, R. S., Greenfield, P., Gomez, E., et al. (2007). Coral reefs under rapid climate change and ocean acidification. Science 318, 1737-1742. doi: 10.1126/science.1152509

Hyndes, G. A., Heck, K. L., Vergés, A., Harvey, E. S., Kendrick, G. A., Lavery, P. S., et al. (2016). Accelerating tropicalization and the transformation of temperate seagrass meadows. Bioscience 66, 938-945. doi: 10.1093/biosci/biw111

Johnson, N. L. (1949). Systems of frequency curves generated by methods of translation. Biometrika 36, 149-176. doi: 10.1093/biomet/36.1-2.149

Jordà, G., Marbà, N., and Duarte, C. M. (2012). Mediterranean seagrass vulnerable to regional climate warming. Nat. Clim. Chang. 2, 821-824. doi: 10.1038/ nclimate 1533

Kant, S., Kant, P., Raveh, E., and Barak, S. (2006). Evidence that differential gene expression between the halophyte, Thellungiella halophila, and Arabidopsis thaliana is responsible for higher levels of the compatible osmolyte proline and tight control of $\mathrm{Na}^{+}$uptake in T. halophila. Plant Cell Environ. 29, 1220-1234. doi: 10.1111/j.1365-3040.2006.01502.x

Katsanevakis, S., and Tsiamis, K. (2009). Records of alien marine species in the shallow coastal waters of Chios Island(2009). Mediterr. Mar. Sci. 10, 99-107.

Lesser, M. P. (1997). Oxidative stress causes coral bleaching during exposure to elevated temperatures. Coral Reefs 16, 187-192. doi: 10.1007/s0033800 50073 
Levene, H. (1960). "Robust tests for equality of variances," in Contributions to Probability and Statistics, ed I. Olkin (Palo Alto, California: Stanford University Press), 278-292.

Liao, E., Lu, W., Yan, X. H., Jiang, Y., and Kidwell, A. (2015). The coastal ocean response to the global warming acceleration and hiatus. Sci. Rep. 5, 1-10. doi: $10.1038 /$ srep 16630

Lima, F. P., and Wethey, D. S. (2012). Three decades of high-resolution coastal sea surface temperatures reveal more than warming. Nat. Commun. 3:704. doi: $10.1038 /$ ncomms1713

Lipkin, Y. (1975a). Halophila stipulacea, a review of a successful immigration. Aquat. Bot. 1, 203-215. doi: 10.1016/0304-3770(75)90023-6

Lipkin, Y. (1975b). Halophila stipulacea in Cyprus and Rhodes, 1967-1970. Aquat. Bot. 1, 309-320. doi: 10.1016/0304-3770(75)90029-7

Livak, K. J., and Schmittgen, T. D. (2001). Analysis of relative gene expression data using real-time quantitative PCR and the $2-\Delta \Delta \mathrm{CT}$ method. Methods 25 , 402-408. doi: 10.1006/meth.2001.1262

Marbà, N., Cebrián, J., Enríquez, S., and Duarte, C. M. (1996). Growth patterns of western Mediterranean seagrasses: species- specific responses to seasonal forcing. Mar. Ecol. Prog. Ser. 133, 203-215. doi: 10.3354/meps133203

Marbà, N., and Duarte, C. M. (2010). Mediterranean warming triggers seagrass (Posidonia oceanica) shoot mortality. Glob. Chang. Biol. 16, 2366-2375. doi: 10.1111/j.1365-2486.2009.02130.x

Maréchal, J. P., Meesters, E. H., Vedie, F., and Hellio, C. (2013). Occurrence of the alien seagrass Halophila stipulacea in Martinique (French West Indies). Mar. Biodivers. Rec. 6, 1-5. doi: 10.1017/S1755267213000961

Marín-Guirao, L., Bernardeau-Esteller, J., García-Muñoz, R., Ramos, A., Ontoria, Y., Romero, J., et al. (2018). Carbon economy of Mediterranean seagrasses in response to thermal stress. Mar. Pollut. Bull. 135, 617-629. doi: 10.1016/j. marpolbul.2018.07.050

Marín-Guirao, L., Ruiz, J. M., Dattolo, E., Garcia-Munoz, R., and Procaccini, G. (2016). Physiological and molecular evidence of differential short-term heat tolerance in Mediterranean seagrasses. Sci. Rep. 6, 28615. doi: 10.1038/ srep28615

Maron, J. L., Vilà, M., Bommarco, R., Elmendorf, S., and Beardsley, P. (2004). Rapid evolution of an invasive plant. Ecol. Monogr. 74, 261-280. doi: 10.1890/03-4027

Mejia, A. Y., Rotini, A., Lacasella, F., Bookman, R., Thaller, M. C., Shem-Tov, R., et al. (2016). Assessing the ecological status of seagrasses using morphology, biochemical descriptors and microbial community analyses. A study in Halophila stipulacea (Forsk.) aschers meadows in the northern Red Sea. Ecol. Indic. 60, 1150-1163. doi: 10.1016/j.ecolind.2015.09.014

Molina-Montenegro, M. A., Acuña-Rodríguez, I. S., Flores, T. S. M., Hereme, R., Lafon, A., Atala, C., et al. (2018). Is the success of plant invasions the result of rapid adaptive evolution in seed traits? Evidence from a Latitudinal rainfall gradient. Front. Plant Sci. 9:208. doi: 10.3389/fpls.2018. 00208

Novy, A., Flory, S. L., and Hartman, J. M. (2013). Evidence for rapid evolution of phenology in an invasive grass. J. Evol. Biol. 26, 443-450. doi: 10.1111/jeb.12047

Oliver, E. C. J., Donat, M. G., Burrows, M. T., Moore, P. J., Smale, D. A., Alexander, L. V., et al. (2018). Longer and more frequent marine heatwaves over the past century. Nat. Commun. 9, 1-12. doi: 10.1038/s41467-018-03732-9

Orth, R. J., Carruthers, T. J. B., Dennison, W. C., Duarte, C. M., Fourqurean, J. W., Heck, K. L., et al. (2006). A global crisis for seagrass ecosystems. AIBS Bull. 56, 987-996.

Oscar, M. A., Barak, S., and Winters, G. (2018). The tropical invasive seagrass, Halophila stipulacea has a superior ability to tolerate dynamic changes in salinity levels compared to its freshwater relative, Vallisneria americana. Front. Plant Sci. 9:950. doi: 10.3389/fpls.2018.00950

Ozer, T., Gertman, I., Kress, N., Silverman, J., and Herut, B. (2017). Interannual thermohaline (1979-2014) and nutrient (2002-2014) dynamics in the Levantine surface and intermediate water masses, SE Mediterranean Sea. Glob. Planet. Chang. 151, 60-67. doi: 10.1016/j.gloplacha.2016.04.001

Procaccini, G., Acunto, S., Famà, P., and Maltagliati, F. (1999). Structural, morphological and genetic variability in Halophila stipulacea (Hydrocharitaceae) populations in the western Mediterranean. Mar. Biol. 135, 181-189. doi: 10.1007/s002270050615

Procaccini, G., Beer, S., Björk, M., Olsen, J., Mazzuca, S., and Santos, R. (2012). Seagrass ecophysiology meets ecological genomics: are we ready? Mar. Ecol. 33, 522-527. doi: 10.1111/j.1439-0485.2012.00518.x
R Core Team, (2018). R: A Language and Environment for Statistical Computing. Vienna: R Foundation for Statistical Computing.

Ralph, P. J. (1998). Photosynthetic response of laboratory-cultured Halophila ovalis to thermal stress. Mar. Ecol. Prog. Ser. 171, 123-130. doi: 10.3354/meps17 1123

Ralph, P. J., and Gademann, R. (2005). Rapid light curves: a powerful tool to assess photosynthetic activity. Aquat. Bot. 82, 222-237. doi: 10.1016/j.aquabot.2005. 02.006

Reiss, Z., and Hottinger, L. (2012). The Gulf of Aqaba: Ecological Micropaleontology. Berlin: Springer.

Rilov, G. (2016). Multi-species collapses at the warm edge of a warming sea. Sci. Rep. 6:36897. doi: 10.1038/srep36897

Rotini, A., Mejia, A. Y., Costa, R., Migliore, L., and Winters, G. (2017). Ecophysiological plasticity and bacteriome shift in the seagrass Halophila stipulacea along a depth gradient in the Northern Red Sea. Front. Plant Sci. 7:2015. doi: 10.3389/fpls.2016.02015

Saroussi, S., and Beer, S. (2007). Alpha and quantum yield of aquatic plants derived from PAM fluorometry: uses and misuses. Aquat. Bot. 86, 89-92. doi: 10.1016/ j.aquabot.2006.09.003

Savva, I., Bennett, S., Roca, G., Jordà, G., and Marbà, N. (2018). Thermal tolerance of Mediterranean marine macrophytes: vulnerability to global warming. Ecol. Evol. 8, 12032-12043. doi: 10.1002/ece3.4663

Schär, C., Vidale, P. L., Lüthi, D., Frei, C., Häberli, C., Liniger, M. A., et al. (2004). The role of increasing temperature variability in European summer heatwaves. Nature 427, 332-336. doi: 10.1038/nature02300

Scheibling, R. E., Patriquin, D. G., and Filbee-Dexter, K. (2018). Distribution and abundance of the invasive seagrass Halophila stipulacea and associated benthic macrofauna in Carriacou, Grenadines, Eastern Caribbean. Aquat. Bot. 144, 1-8. doi: 10.1016/j.aquabot.2017.10.003

Serra, I. A., Lauritano, C., Dattolo, E., Puoti, A., Nicastro, S., Innocenti, A. M., et al. (2012). Reference genes assessment for the seagrass Posidonia oceanica in different salinity, $\mathrm{pH}$ and light conditions. Mar. Biol. 159, 1269-1282. doi: 10.1007/s00227-012-1907-8

Sghaier, Y. R., Zakhama-Sraieb, R., Benamer, I., and Charfi-Cheikhrouha, F. (2011). Occurrence of the seagrass Halophila stipulacea (Hydrocharitaceae) in the southern Mediterranean Sea. Bot. Mar. 54, 575-582.

Sghaier, Y. R., Zakhama-sraieb, R., and Charfi-cheikhrouha, F. (2014). "Effects of the invasive seagrass Halophila stipulacea on the native seagrass Cymodocea nodosa," in Proceedings of the 5th Mediterranean Symposium on Marine Vegetation, (Portorož, Sl: UNEP), 167-171. doi: 10.13140/2.1.3086. 6888

Sharkey, T. D. (2005). Effects of moderate heat stress on photosynthesis: importance of thylakoid reactions, rubisco deactivation, reactive oxygen species, and thermotolerance provided by isoprene. Plant. Cell Environ. 28, 269-277. doi: 10.1111/j.1365-3040.2005.01324.x

Sharon, Y., Levitan, O., Spungin, D., Berman-Frank, I., and Beer, S. (2011). Photoacclimation of the seagrass Halophila stipulacea to the dim irradiance at its 48-meter depth limit. Limnol. Oceanogr. 56, 357-362. doi: 10.4319/lo.2011. 56.1.0357

Short, F. T., and Neckles, H. A. (1999). The effects of global climate change on seagrasses. Aquat. Bot. 63, 169-196. doi: 10.1016/s0304-3770(98)00117-x

Short, F. T., Polidoro, B., Livingstone, S. R., Carpenter, K. E., Bandeira, S., Bujang, J. S., et al. (2011). Extinction risk assessment of the world's seagrass species. Biol. Conserv. 144, 1961-1971.

Smith, T. M. (2016). A long-term record of blended satellite and in situ sea-surface temperature for climate monitoring, modeling and environmental studies. Earth Syst. Sci. Data 8, 165-176.

Stachowicz, J. J., Fried, H., Osman, R. W., and Whitlach, R. B. (2002). Biodiversity, invasion resistance and marine ecosystem function. Ecology 83, 2575-2590. doi: 10.1890/0012-9658(2002)083\%5B2575:birame\%5D2.0.co;2

Steiner, S. C. C., and Willette, D. A. (2015). The expansion of Halophila stipulacea (Hydrocharitaceae, Angiospermae) is changing the seagrass landscape in the commonwealth of dominica lesser antiles. Caribb. Nat. 22, 1-19.

Streftaris, N., and Zenetos, A. (2006). Alien marine species in the mediterranean the 100 'worst invasives' and their impact. Mediterr. Mar. Sci. 7, 87-118. doi: $10.12681 / \mathrm{mms} .180$

Sultan, S. E., Horgan-Kobelski, T., Nichols, L. M., Riggs, C. E., and Waples, R. K. (2013). A resurrection study reveals rapid adaptive evolution within 
populations of an invasive plant. Evol. Appl. 6, 266-278. doi: 10.1111/j.17524571.2012.00287.x

Tran, T. H., Mayzlish Gati, E., Eshel, A., and Winters, G. (2018). Germination, physiological and biochemical responses of acacia seedlings (Acacia raddiana and Acacia tortilis) to petroleum contaminated soils. Environ. Pollut. 234, 642-655. doi: 10.1016/j.envpol.2017.11.067

Tutar, O., Marín-Guirao, L., Ruiz, J. M., and Procaccini, G. (2017). Antioxidant response to heat stress in seagrasses. A gene expression study. Mar. Environ. Res. 132, 94-102. doi: 10.1016/j.marenvres.2017.10.011

Tyberghein, L., Verbruggen, H., Pauly, K., Troupin, C., Mineur, F., and De Clerck, O. (2012). Bio-ORACLE: a global environmental dataset for marine species distribution modelling. Glob. Ecol. Biogeogr. 21, 272-281. doi: 10.1111/ j.1466-238.2011.00656.x

Unsworth, R. K. F., Collier, C. J., Henderson, G. M., and McKenzie, L. J. (2012). Tropical seagrass meadows modify seawater carbon chemistry: implications for coral reefs impacted by ocean acidification. Environ. Res. Lett. 7:2. doi: 10.1088/1748-9326/7/2/024026

van der Velde, G., and den Hartog, C. (1992). Continuing range extension of Halophila stipulacea (Forssk.) Aschers. (Hydrocharitaceae) in the Mediterranean-now found at Kefallinia and Ithaki (Ionian Sea). Acta Bot. Neerl. 41, 345-348. doi: 10.1111/j.1438-8677.1992.tb01341.x

van Tussenbroek, B. I., van Katwijk, M. M., Bouma, T. J., van der Heide, T., Govers, L. L., and Leuven, R. S. E. W. (2016). Non-native seagrass Halophila stipulacea forms dense mats under eutrophic conditions in the Caribbean. J. Sea Res. 115, 1-5. doi: 10.1016/j.seares.2016.05.005

Vera, B., Collado-Vides, L., Moreno, C., and Tussenbroek, B. I. V. (2014). Halophila stipulacea (Hydrocharitaceae): a recent introduction to the continental waters of Venezuela. Caribb. J. Sci. 48, 66-70. doi: 10.18475/cjos.v48i1.a11

Warren, C. R. (2008). Rapid measurement of chlorophylls with a microplate reader. J. Plant Nutr. 31, 1321-1332. doi: 10.1080/01904160802135092

Waycott, M., Duarte, C. M., Carruthers, T. J. B., Orth, R. J., Dennison, W. C., Olyarnik, S., et al. (2009). Accelerating loss of seagrasses across the globe threatens coastal ecosystems. Proc. Natl. Acad. Sci. U.S.A. 106, 12377-12381. doi: 10.1073/pnas.0905620106

Wellburn, A. R. (1994). The spectral determination of chlorophylls a and b, as well as total carotenoids, using various solvents with spectrophotometers of different resolution. J. Plant Physiol. 144, 307-313. doi: 10.1016/s0176-1617(11) 81192-2

Willette, D. A., and Ambrose, R. F. (2009). The distribution and expansion of the invasive seagrass Halophila stipulacea in Dominica, West Indies, with a preliminary report from St. Lucia. Aquat. Bot. 91, 137-142. doi: 10.1016/j. aquabot.2009.04.001
Willette, D. A., and Ambrose, R. F. (2012). Effects of the invasive seagrass Halophila stipulacea on the native seagrass, Syringodium filiforme, and associated fish and epibiota communities in the Eastern Caribbean. Aquat. Bot. 103, 74-82. doi: 10.1016/j.aquabot.2012.06.007

Willette, D. A., Chalifour, J., Debrot, A. O. D., Engel, M. S., Miller, J., Oxenford, H. A., et al. (2014). Continued expansion of the trans-Atlantic invasive marine angiosperm Halophila stipulacea in the Eastern Caribbean. Aquat. Bot. 112, 98-102. doi: 10.1016/j.aquabot.2013.10.001

Winters, G., Edelist, D., Shem-Tov, R., Beer, S., and Rilov, G. (2017). A low cost field-survey method for mapping seagrasses and their potential threats: an example from the northern Gulf of Aqaba, Red Sea. Aquat. Conserv. Mar. Freshw. Ecosyst. 27, 324-339. doi: 10.1002/aqc.2688

Winters, G., Loya, Y., and Beer, S. (2006). In situ measured seasonal variations in $\mathrm{F} v / \mathrm{F} \mathrm{m}$ of two common Red Sea corals. Coral Reefs 25, 593-598. doi: 10.1007/s00338-006-0144-3

Winters, G., Nelle, P., Fricke, B., Rauch, G., and Reusch, T. B. H. (2011). Effects of a simulated heat wave on photophysiology and gene expression of high-and low-latitude populations of Zostera marina. Mar. Ecol. Prog. Ser. 435, 83-95. doi: 10.3354/meps09213

Wyllie-Echeverria, S., and Cox, P. A. (1999). The seagrass (Zostera marina [Zosteraceae]) industry of Nova Scotia (1907-1960). Econ. Bot. 53, 419-426. doi: 10.1007/BF02866721

Zelikova, T. J., Hufbauer, R. A., Reed, S. C., Wertin, T., Fettig, C., and Belnap, J. (2013). Eco-evolutionary responses of Bromus tectorum to climate change: implications for biological invasions. Ecol. Evol. 3, 1374-1387. doi: 10.1002/ ece 3.542

Zhang, C. G., Leung, K. K., Wong, Y. S., and Tam, N. F. Y. (2007). Germination, growth and physiological responses of mangrove plant (Bruguiera gymnorrhiza) to lubricating oil pollution. Environ. Exper. Bot. 60, 127-136. doi: 10.1016/j. envexpbot.2006.09.002

Conflict of Interest: The authors declare that the research was conducted in the absence of any commercial or financial relationships that could be construed as a potential conflict of interest.

Copyright (C) 2020 Nguyen, Yadav, Barak, Lima, Sapir and Winters. This is an openaccess article distributed under the terms of the Creative Commons Attribution License (CC BY). The use, distribution or reproduction in other forums is permitted, provided the original author(s) and the copyright owner(s) are credited and that the original publication in this journal is cited, in accordance with accepted academic practice. No use, distribution or reproduction is permitted which does not comply with these terms. 